\title{
A cirkon (U-Th)/He kormeghatározás módszertani alapjai és alkalmazása fiatal (<1 M év) vulkánkitörések datálására
}

\author{
MolnÁR Kata ${ }^{1, *}$, DunKL István ${ }^{2}$, HARANGI Szabolcs ${ }^{1,3}$, LuKÁCs Réka ${ }^{3}$
}

${ }^{1}$ Eötvös Loránd Tudományegyetem, Földrajz- és Földtudományi Intézet, Kőzettan-Geokémiai Tanszék, Budapest ${ }^{2}$ Department of Sedimentology and Environmental Geology, Geoscience Centre, Georg-August University, Göttingen, Germany ${ }^{3}$ MTA-ELTE Vulkanológiai Kutatócsoport, Budapest

*levelezô szerző, email: mkata90@gmail.com

\section{Methodology and application of zircon $(U-T h) / H e$ geochronology in the dating of young $(<1$ Ma) eruptions}

Abstract

The dating of young volcanic eruptions is often difficult with respect to the time range between the sensitivities of radiocarbon and the routine $\mathrm{K}-\mathrm{Ar}$ methods (ca. $50 \mathrm{ka}$ and $1 \mathrm{Ma}$, respectively); problems can also arise due to the absence of suitable K-bearing minerals (e.g. leucite, sanidine) or charcoal fragments. However, by combining zircon U-Th and (U$\mathrm{Th}) / \mathrm{He}$ dating this critical time-window can be covered. Because of the low closure temperature of the zircon $(\mathrm{U}-\mathrm{Th}) / \mathrm{He}$ system $\left(\sim 150-180{ }^{\circ} \mathrm{C}\right)$, and the fact that zircon is a widespread accessory mineral in most of the volcanic eruption products, this method is suitable for dating the age of eruptions directly. Furthermore, over the last decade,the advantages of the method have been supported by its expansion and application by international researchers when dating young $(<1$ Ma) eruption events. In this Hungarian review paper a summary is presented of the theoretical principles, basic methodology and past developments of the (U-Th)/He geochronology; it also shows the applicability of the method for dating young $(<1 \mathrm{Ma})$ volcanic eruptions.

For the purpose of this study eruption products were selected from the Carpathian-Pannonian Region and they are related to the youngest volcanic activity (Ciomadul, South Harghita) known in the area. These are the andesitic dome of Dealul Mare and the pyroclastic deposit close to the village of Bixad; these features have eruption ages of $843 \pm 27 \mathrm{kyrs}$ and $32.6 \pm 1.0 \mathrm{kyrs}$, respectively. The selected samples are good for demonstrating each step of the method from the measured raw data to the corrected age, and also for illustrating its adequacy for deriving reliable eruption ages for young volcanic products.

Keywords: (U-Th)/He geochronology, disequilibrium dating, zircon, Carpathian-Pannonian Region, Quaternary

Összefoglalás

A fiatal vulkánkitörések kormeghatározása sokszor igen nagy nehézségbe ütközik a konvencionálisan használt módszerek időbeli korlátai (pl.: radiokarbon — 50 ezer év a felső korhatár; K-Ar — 1 millió év a rutinmérések alsó korhatára), vagy a méréshez szükséges megfelelő ásványok (pl. leucit, szanidin), valamint szenesedett növénymaradványok hiányában. Az U-Th mérésekkel kiegészített cirkon (U-Th)/He geokronológia többek között erre a kritikus időintervallumra kínál megoldási lehetőséget. Alacsony záródási hőmérséklete $\left(\sim 150-180{ }^{\circ} \mathrm{C}\right)$ miatt képes a kitörés időpontjáról direkt információt adni, továbbá nagy előnye az is, hogy a cirkon egy igen széleskörúen elterjedt akceszszórikus ásvány a legtöbb vulkáni kitörési termékben. Mindezekből kifolyólag az elmúlt évtized alatt a nemzetközi kutatások során egyre elterjedtebbé vált a módszer alkalmazása a fiatal (<1 millió év) kitörések datálására is, azonban a hazai kutatásokban csak kis mértékben jelent meg ugyanez a tendencia. Jelen munka célja, hogy az (U-Th)/He geokronológia elméleti és gyakorlati alapjairól, valamint fiatal vulkánkitörések kormeghatározása esetében történó alkalmazhatóságáról nyújtson egy részletes, magyar nyelvú összefoglalást.

Az alkalmazhatóság vizsgálatára a Kárpát-Pannon térség legfiatalabb vulkánkitörésének (Csomád, Dél-Hargita) környezetében megtalálható, ahhoz kapcsolódó kitörési termékeket választottunk. Ezek a Nagy-Hegyes andezit lávadómja és a bükszádi piroklasztár-üledék, amelyekre $843 \pm 27$ ezer (Nagy-Hegyes felépülése) és 32,6 \pm 1,0 ezer évet (bükszádi réteget létrehozó kitörés) kaptunk eredményül. A kiválasztott lelőhelyek mintáin keresztül jól szemléltethető, hogy miként történik az (U-Th)/He kormeghatározás, hogyan követik egymást az egyes lépések, amíg eljutunk a mért adattól a végleges koreredményig. Ezek a képződmények jó példát szolgáltatnak a módszer alkalmazhatóságának bemutatására fiatal (<1 millió év) vulkánkitörések kormeghatározására.

Tárgyszavak: geokronológia, vulkanológia, $(U-T h) / H e$ kormeghatározás, nem egyensúlyi kormeghatározás, cirkon, Kárpát-Pannon régió, kvarter 


\section{Bevezetés}

Az U- és Th-izotópok radioaktív bomlásából származó, és az ásványokban felhalmozódó He geokronológiai jelentőségét és alkalmazhatóságát már viszonylag korán, alig 10 évvel a radioaktivitás felfedezése után felismerte Robert J. STRUTT (1905). Úttörố munkája ellenére majdnem egy évszázadot kellett várni a módszer elterjedésére, ugyanis elsőre megbízhatatlannak túnt, mivel a korai kutatások során kapott koreredmények túl fiatalnak bizonyultak (pl.: LEVENTHAL 1975). Ennek oka, hogy egy geokronológiai módszer használata során a kapott kor mindig azt az időpontot határozza meg, amikor az adott izotóprendszer zárttá válik, tehát a rendszer hőmérséklete az abban szereplő izotópokra vonatkozó záródási hőmérséklet alá húl (DoDSON 1973). Azonban csak a nyolcvanas években ismerték fel (ZEITLER et al. 1987, LiPPOLT \& Weigel 1988), hogy ellentétben a magas hőmérsékleten záródó $\mathrm{U}-\mathrm{Pb}$ rendszerrel, az (U-Th)/He esetében a kapott kor a hasadványnyom módszerhez hasonlóan az alacsony hőmérséklet-tartományról, adott rendszer kései hőtörténetéről adhat információt. Ezáltal a korábbi „túl fiatal” korok más értelmet nyertek és megújult érdeklődéssel fordultak a módszer felé. Az (UTh)/He geokronológia fejlődésnek indult, a különböző kutatások során egyre szélesebb körben, számos geológiai kérdés (pl.: adott terület süllyedés-kiemelkedés-története) megválaszolására, az apatit mellett egyre többféle ásvány (pl.: cirkon, titanit, hematit) bevonásával kezdték alkalmazni (pl.: FARLEY et al. 1996, WERNICKE \& LIPPOLT 1997, SPOTILA et al. 1998, McInNes et al. 1999). Emellett felismerték azt is, hogy a módszer — kombinálva az U-Th kormeghatározással — lehetôséget ad vulkánkitörések kormeghatározására is, amely különösen a fiatal (kvarter) események kapcsán jelentős. Ugyanis, amint az ScHMITT és munkatársai (2006) egyik első, ilyen témájú munkájából is kiderült, jól alkalmazható abban a kritikus időintervallumban ( 50 ezer év — 1 millió év) is, ahol a módszertani korlátok vagy megfelelő ásványok hiányában más geokronológiai módszerek (pl.: radiokarbon, K-Ar) nem adnak megfelelően pontos korokat (FARLEY 2002; DANIŠíK et al. 2016). Ezt követően egyre több olyan tanulmány jelent meg, amelynek fókuszában fiatal vulkánkitörések datálása állt (pl.: DANišíK et al. 2012; SCHMITT et al. 2010, 2013, 2014; LiNDSAY et al. 2013; GeBAUER et al. 2014; HARANGi et al. 2015a). Az ezekben közölt eredmények azt mutatták, hogy nem csak az 50 ezer és 1 millió év közötti időintervallumban, hanem még az ennél fiatalabb minták esetében is jól használható az (U-Th)/He geokronológia (legfiatalabb mért korok: cirkon (U-Th)/He - 2,5 ezer év; ScHMITT et al. 2013; gránát (U-Th)/He — A.D. 79; ACIEGO et al. 2003).

A módszer újrafelfedezését (ZEITLER et al. 1987) követően és szélesebb körú elterjedésével párhuzamosan megjelentek a módszertani jellegú leírások (FARLEY 2002, REINERS 2005, SCHMITT 2011, DANIŠíK et al. 2016), amelyek segítségével megindultak a nemzetközi laboratóriumokban a rutinszerû (U-Th)/He mérések. Ennek ellenére hazai viszonylatban csak kis számban született olyan esettanul- mány, amely a módszer termokronológiai vonatkozású (pl.: ARATÓ 2014, DANIŠí́K et al. 2015, LuKÁcs et al. 2015), vagy a vulkánkitörések kormeghatározására történő (pl.: KARÁTSOn et al. 2013, MolnÁr 2014, HARANGi et al. 2015a) alkalmazását használta. Jelen tanulmány célja, hogy egy magyar nyelvû elméleti összefoglalót adjunk az eddig a témakörben megjelent publikációk alapján, valamint hogy saját példákon keresztül bemutassuk a módszer alkalmazhatóságát a fiatal vulkánkitörések kormeghatározása esetében.

\section{Módszertani alapok}

A radiogén hélium $\left({ }^{4} \mathrm{He}\right)$ a radioaktív izotópok (pl.: ${ }^{238} \mathrm{U}$ $\left.\rightarrow{ }^{206} \mathrm{~Pb},{ }^{235} \mathrm{U} \rightarrow{ }^{207} \mathrm{~Pb},{ }^{232} \mathrm{Th} \rightarrow{ }^{208} \mathrm{~Pb},{ }^{147} \mathrm{Sm} \rightarrow{ }^{143} \mathrm{Nd}\right)$ alfabomlásai során képződik (egy $\alpha$-bomlási esemény egy ${ }^{4} \mathrm{He}$ képződést jelent). Az (U-Th)/He módszer az ásványokba kristályosodásuk során beépülő izotópok radioaktív bomlásakor keletkező és felhalmozódó He mennyiségének a meghatározásán alapul. Azok az ásványok alkalmasak az (UTh)/He kormeghatározásra, amelyekbe kristályosodásukkor olyan mennyiségben épülnek be az anyaizotópok, hogy ezek bomlása során adott idő alatt mérhető mennyiségú He keletkezik. Ilyen például az apatit (pl.: HousE et al. 1999), titanit (pl.: REINERS \& FARLEY 1999), cirkon (pl.: DANISÍK et al. 2012, SchmitT et al. 2014), hematit (pl.: EvEnson et al. 2014, Ault et al. 2015), fluorit (pl.: Evans et al. 2005, WolfF et al. 2015), valamint a gránát (pl.: ACIEGo et al. 2003). Ezek közül az apatitot és a cirkont használják rutinszerúen a He-mérések során, a továbbiakban ennek a tanulmánynak a fókuszában a cirkon áll.

Az ásványban jelenlevő He teljes mennyiségét $\left({ }^{4} \mathrm{He}_{\text {tot }}\right)$ a következő (1.) egyenlet írja le (FARLEY 2002, HourigAN et al. 2005):

$$
\begin{aligned}
{ }^{4} H e_{\mathrm{tot}}=H e_{i}+ & 8 \times{ }^{238} U\left(e^{\lambda_{238^{t}}}-1\right)+ \\
& 7 \times{ }^{235} U\left(e^{\lambda_{235} t}-1\right)+ \\
& 6 \times{ }^{232} \mathrm{Th}\left(e^{\lambda_{232} t}-1\right)+ \\
& 1 \times{ }^{147} \operatorname{Sm}\left(e^{\lambda_{147^{t}}}-1\right),
\end{aligned}
$$

ahol ${ }^{4} \mathrm{He}_{\text {tot }},{ }^{238} \mathrm{U},{ }^{232} \mathrm{Th}$ és ${ }^{147} \mathrm{Sm}$ az adott tömegszámú izotóp jelenkori mért mennyisége, míg a nagyon kis részarányban előforduló ${ }^{235} \mathrm{U}$ mennyisége a jelenlegi ${ }^{235} \mathrm{U} /{ }^{238} \mathrm{U}$ arányból $\left({ }^{238}\right.$ U/137,818; Hiess et al. 2012) számolható ki. A $H e_{i}$ az iniciális hélium mennyisége, $t$ a bezáródás óta eltelt idő, vagyis a felhalmozódási idő, $\lambda$ pedig a bomlási állandó az egyes izotópokra $\left(\lambda_{238}=1,551 \times 10^{-10} \mathrm{év}^{-1}, \lambda_{235}=9,849 \times 10^{-10}\right.$ év ${ }^{-1}, \lambda_{232}=4,948 \times 10^{-11}$ év $\left.^{-1}\right)$. A ${ }^{238} \mathrm{U},{ }^{235} \mathrm{U}$ és ${ }^{232} \mathrm{Th}$ izotópok bomlási sorában több, köztes radioaktív izotóp keletkezése és bomlása is végbemegy, míg eljut az adott izotóprendszer a stabil leányizotópig $\left({ }^{206} \mathrm{~Pb},{ }^{207} \mathrm{~Pb}\right.$ és ${ }^{208} \mathrm{~Pb} ; 1$. ábra $)$. Ezzel szemben a kristályosodáskor kis mennyiségben szintén beépülő ${ }^{147} \mathrm{Sm}$ esetében a ${ }^{144} \mathrm{Nd}$ keletkezéséhez csupán egy alfa bomlás szükséges. Az (1.) egyenlet egyes tagjai előtt álló szorzók (8, 7, 6, valamint 1) tehát az adott izotóprendszeren belül történő alfa bomlások számát mutatják. Az 

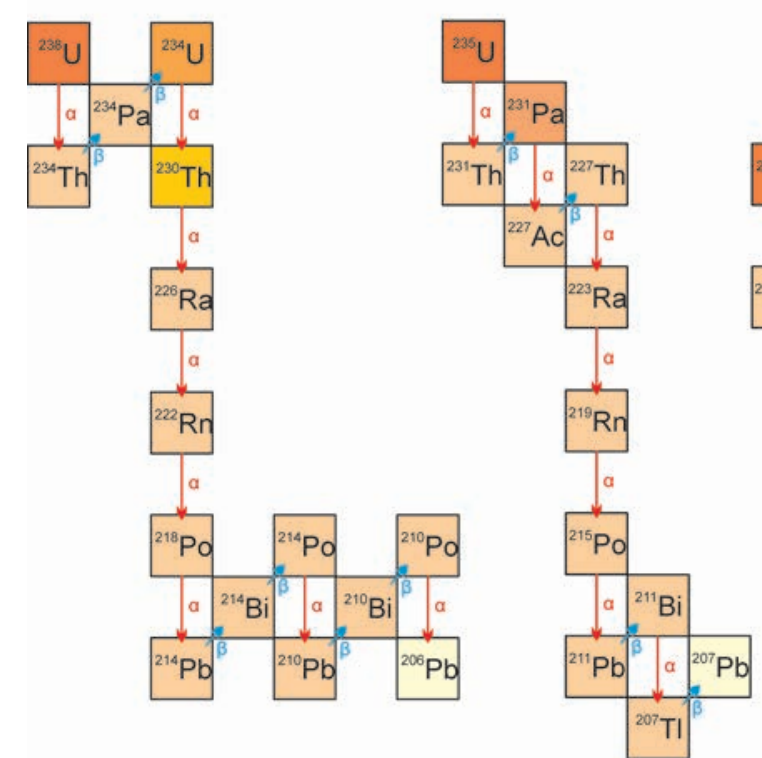

felezési idő

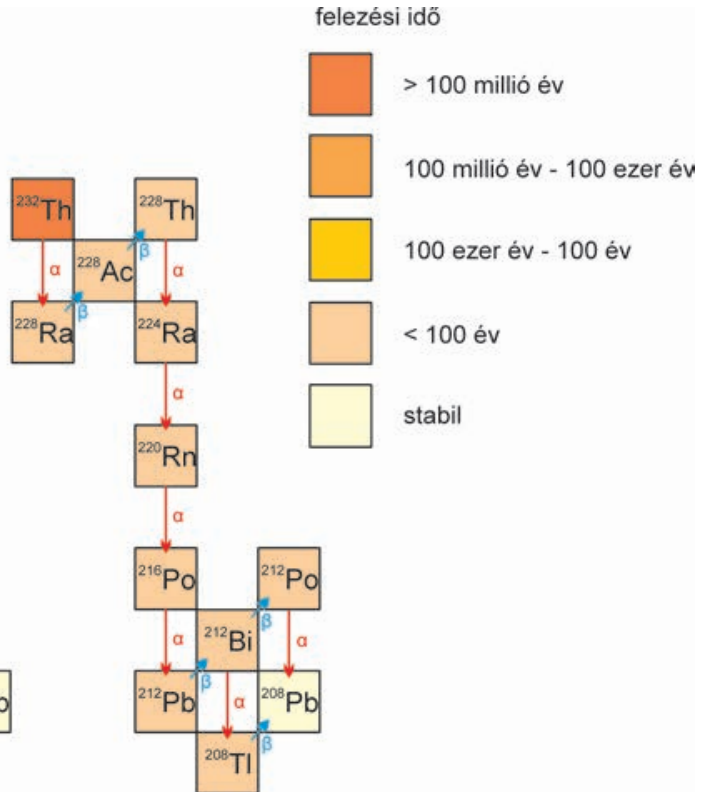

1. ábra. $\mathrm{A}{ }^{238} \mathrm{U}$-, ${ }^{235} \mathrm{U}$ - és ${ }^{232} \mathrm{Th}$ bomlási sora, feltüntetve az $\alpha-\left({ }^{4} \mathrm{He}\right)$ és $\beta$-bomlási eseményeket (https://research.science.mq.edu.au/useries-research-group/facil.html alapján)

Figure 1. The ${ }^{238} U$-, ${ }^{235} \mathrm{U}$ - and ${ }^{232}$ Th decay chain indicating $\alpha-\left({ }^{4} H e\right)$ and $\beta$-decay events (after https://research.science.mq.edu.au/u-seriesresearch-group/facil.html)

(1.) egyenlet alapfeltételezése a szekuláris egyensúly megléte a radioaktív bomlási sorokon belül (FARLEY 2002, REINERS 2005), ami azt jelenti, hogy az egységnyi idó alatt történő bomlások száma adott köztes leányizotópra és a hozzá tartozó anyaizotópra megegyezik (tehát az aktivitásarányuk 1; BATEMAN 1910). Ez azonban nem minden esetben valósul meg, amelynek oka, hogy az ásványok a kristályosodásuk során frakcionálhatják egymástól a bomlási sorban szereplő izotópokat, felborítva ezzel a szekuláris egyensúlyt (FARLEY et al. 2002, SchMitT 2011). Ekkor, a kezdeti körülményektől függetlenül, az adott bomlási sorban szereplő, leghosszabb életú frakcionálódó izotóp felezési idejének kb. ötszöröse kell, hogy elteljen a szekuláris egyensúly beállásához (FARLEY et al. 2002). Tehát az alapegyenlet (1.) csak abban az esetben alkalmazható, ha a kristály képződése legalább 380 ezer évvel megelózte a ${ }^{4} \mathrm{He}$ felhalmozódás kezdetét (FARLEY 2002).

Ezen felül az (U-Th)/He módszer alapfeltétele, hogy a mért kristály kezdetben nem tartalmazott héliumot, amely az esetek nagy többségében teljesül is (tehát $\mathrm{He}_{\mathrm{i}}=0$; FARLEY 2002, REINERS 2005).

\section{Záródási hömérséklet}

Geokronológiai módszertôl és vizsgált ásványtól függetlenül záródási hőmérsékletnek nevezzük azt a hőmérsékletet/hőmérséklet-tartományt, amely érték elérését követően az adott izotóprendszer zártnak tekinthetô, tehát amely hőmérséklet alatt a keletkező leányizotóp megőrződik az adott ásványban (2. ábra, A; Dodson 1973). A különböző geokronológiai módszerek használatakor a meghatározott kor mindig azt az időpontot jelöli, amikor az adott rendszer a záródási hőmérséklete/hőmérséklet-tartománya alá húl (2.

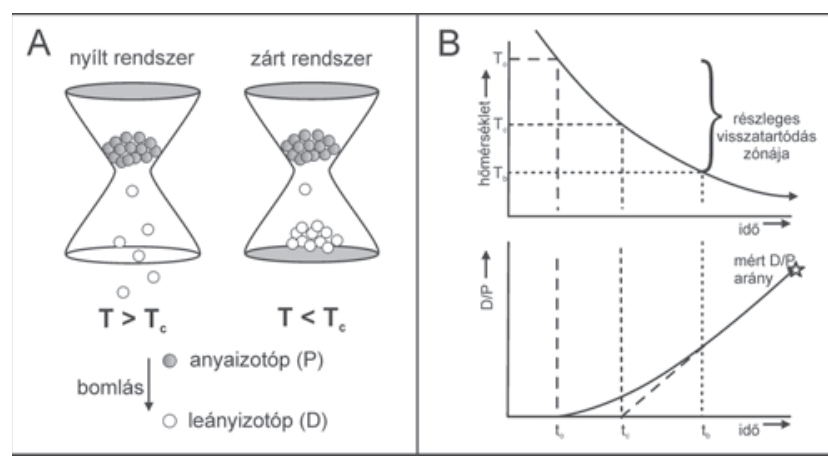

2. ábra. A)„Homokóra-analógia” a nyílt és a zárt rendszerủ viselkedésre (BRAUN et al. 2012 alapján). B) Lassan hülő rendszer esetén a „nyílt-rendszerü” ( $\left.\mathrm{T}_{\mathrm{o}}\right)$, záródási $\left(\mathrm{T}_{\mathrm{c}}\right)$ és blokkolási $\left(\mathrm{T}_{\mathrm{b}}\right)$ hőmérséklet fogalma, és az ezeknek megfelelö időpillanatokban $\left(t_{0}, t_{c}, t_{b}\right)$ a leány-/anyaizotóp arány. $T_{0}$ hőmérséklet felett tisztán nyilt rendszer, míg $\mathrm{T}_{\mathrm{b}}$ alatt tisztán zárt rendszer uralkodik. A két hőmérsékletérték jelöli ki a részleges visszatartódás zónáját (DoDSON 1973 és BRAUN et al. 2012 alapján)

Figure 2. A) Hourglass analogy to open- and closed-system behavior (after BRAUN et al. 2012). B) Definition of the "open-system", closure and blocking temperatures $\left(T_{o}, T_{c}\right.$ and $T_{b}$, respectively) in a slowly cooling system and the daughter-parent isotope ratios at the corresponding $t_{o}, t_{c}$ and $t_{b}$ time. The temperature range of $T_{o}-T_{b}$ assign the partial retention zone, above its upper boundary the system has a fully open-system behavior while it has a fully closed-system behavior below the lower boundary (after DODSON 1973 and BRAUN et al. 2012)

ábra, B). Az egyes rendszerekre ezt a hőmérséklet-tartományt az adott rendszer leányizotópjának ásvány-függó diffúziós viselkedése határozza meg. Ez az egyes ásványokra különböző fizikai paraméterekkel jellemezhető környezetekben, laboratóriumi, lépcsőzetes hevítési kísérletek során határozható meg, a megfigyelt diffúziós viselkedés pedig az Arrhenius-egyenlet (2.) segítségével írható le:

$$
D=D_{0} e^{-E_{0} / R T},
$$


ahol $D$ a diffúziós együttható adott $T$ hőmérsékleten, $E_{a}$ az aktivációs energia, $R$ az egyetemes gázállandó, $D_{0}$ pedig a diffúziós együttható egy végtelenül nagy hőmérsékleten, vagyis a diffúziós állandó (Fechtig \& KALBITzer 1966). Ebből az összefüggésből (2. egyenlet) a záródási hőmérséklet $\left(T_{c}\right)$ bármely izotóp-rendszerre és ásványra a következőképp fejezhető ki (3. egyenlet; 3. ábra):

$$
T_{\mathrm{c}}=\frac{E_{\mathrm{a}}}{R \ln \left(A \tau D_{0} / a^{2}\right)},
$$

ahol $A$ egy, a kristály geometriájától függő numerikus konstans, $a$ az adott kristály mérete, $\tau$ pedig az az idő, amely alatt a diffúzió $e$ faktornyit csökken — ez utóbbi a rendszer húlési rátájának függvénye (DoDson 1973). Az egyenletből (3.) látszódik, hogy a záródási hőmérséklet-tartomány alsó és felső határát az adott izotóp diffúziós tulajdonságai mellett a

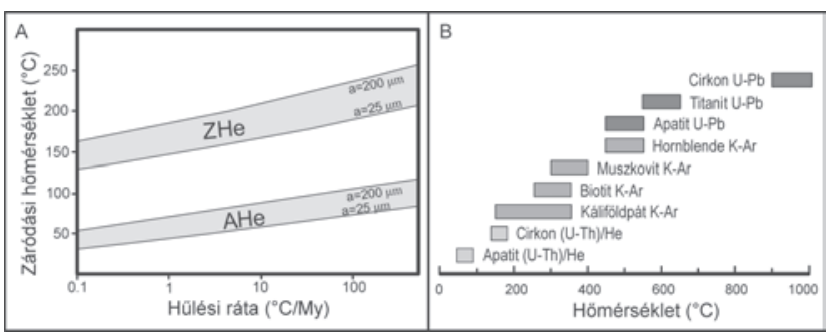

3. ábra. A) apatit ( $\mathrm{AHe})$ és cirkon ( $\mathrm{ZHe})$ záródási hőmérséklet-tartomány változása szemcseméret („a”) és hűlési ráta függvényében (REINERS 2005 alapján). B) Különböző izotóprendszerekre és ásványokra meghatározott átlagos záródási hỏmérséklet-tartományok (apatit (U-Th)/He: WoLF et al. 1996; cirkon (U-Th)/He: REINERS et al. 2004; káliföldpát K-Ar: LOVERA et al. 1989; biotit K-Ar: HARRISON et al. 1985; muszkovit K-Ar: HAMES \& BOWRING 1994; hornblende K-Ar: Harrison 1982; apatit és titanit U-Pb: SchoENE \& BOWRING 2007; cirkon U-Pb: LEE et al. 1997).

Figure 3. A) calculated closure temperatures for apatite (AHe) and zircon ( $\mathrm{ZHe})$ and their cooling rate- and grain size ("a")-dependence (after REINERS 2005). B) Closure temperature ranges of different minerals and isotope systems (apatite ( $U$ Th)/He: Wolf et al. 1996; zircon (U-Th)/He: REINERS 2005; K-feldspar K-Ar: LOVERA et al. 1989; biotite K-Ar: HARRISON et al. 1985; muscovite K-Ar: HAMES \& BOWRING 1994; hornblende K-Ar: HARRISON 1982; apatite and titanite U-Pb: SCHOENE \& BOWRING 2007; zircon U-Pb: LEE et al. 1997).

szemcse alaki és méretbeli tulajdonságai, valamint a húlési ráta határozza meg (3. ábra, A). A záródási hőmérséklettartományt nevezik részleges visszatartódási zónának is. Ennek a felső határánál magasabb hőmérsékleten az összes bomlás során a keletkező leányizotóp földtani értelemben véve pillanatszerû diffúzióval távozik az adott ásványból, míg alsó határánál alacsonyabb hőmérsékleten 100\%-osnak tekinthető a megőrződés. A két szélsőérték között a vizsgált izotóp felhalmozódása nem kvantitatív, az adott kristály alakjától és méretétől, valamint a rendszer húlési rátájától függően csak egy adott rész tartódik vissza (2. ábra, $B$ ).

Tehát az (U-Th)/He módszer esetében a záródási hőmérséklet a radioaktív bomláskor keletkező He diffúziós tulajdonságaitól függ. A cirkonon végzett kísérletek a következő eredményt hozták a He diffúziójára: egy tipikus, 40-100 $\mu \mathrm{m}$ vastagságú cirkon záródási hőmérséklete $175^{\circ} \mathrm{C}$ és $193{ }^{\circ} \mathrm{C}$ közötti érték abban az esetben, ha a húlési ráta $10^{\circ} \mathrm{C} /$ millió év és a kristály nem tartalmaz extrém nagy mennyiségben radioaktív izotópokat (REINERS 2005, GUENTHNER et al. 2013). A kísérletek során kapott hőmérsékletértékek tehát azt mutatják, hogy az (U-Th)/He módszer egy alacsony hőmérsékletú geokronológiai módszer (3. ábra, $A$ és $B$ ), amely a kőzettestek fejlődésének kései szakaszáról, a kis mélységben végbement hőtörténetről ad értékes információkat. Adott leányizotóp ásványfüggésére jó példa az apatit és a cirkon záródási hőmérséklet-tartománya közti eltérés az (UTh)/He rendszer esetében (3. ábra, $A$ és $B$ ), míg ugyanazon ásványt vizsgálva az eltérô leányizotópok különböző diffúziós viselkedését jól tükrözi a cirkon (U-Th)/He és U-Pb rendszer (3. ábra, B). Ez utóbbi sokkal magasabb hőmérsékleten (>900 두 LEE et al. 1997; 3. ábra, B) záródik, mint az (U-Th)/He rendszer, és így jól alkalmazható a cirkon kristályosodási korának meghatározására, ami általában $900{ }^{\circ} \mathrm{C}$ alatt történik (HARRISON et al. 2007).

A „He-termokronológiát” az alacsony záródási hőmérséklet miatt széles körben lehet alkalmazni különböző geológiai kérdések megválaszolására (pl.: diagenetikus hőmérsékleti hatások és hidrotermális események datálására, mély völgyek bevágódási ütemének megállapítására; HouSE et al. 1997, HAIDER et al. 2013, REINERS \& BRANDON 2006, SCHILDGEN et al. 2007, WolfF et al. 2015). Abban az esetben, ha egy hirtelen a felszínre került, gyorsan lehúlt vulkáni kőzetet vizsgálunk, amely a kitörés során (geológiai időskálán nézve) gyorsan áthaladt a részleges visszatartódási zóna hômérséklet-tartományán, és amelyet nem ért későbbi hőhatás (pl. betemetődés vagy egy fiatalabb intrúzió hatása)
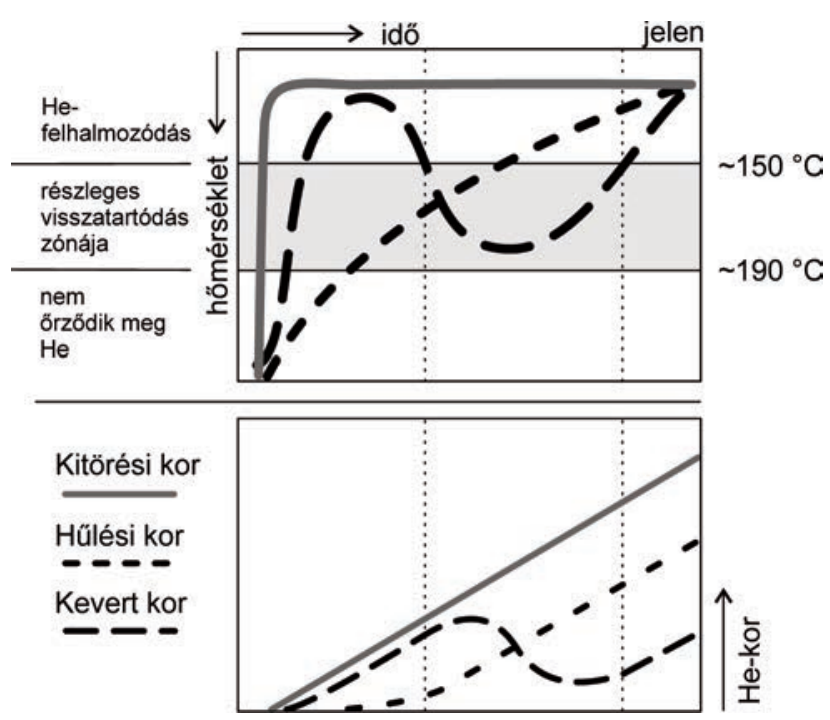

4. ábra. A kitörési-, hủlési- és kevert kor jelentése cirkonra vonatkozó hőmérsékletek esetében (WAGNER 1979 alapján). Kitörési kor: egy hirtelen felszínre került vulkáni kőzet (U-Th)/He kora, a He-felhalmozódás a kitörés pillanatában kezdődik. Hủlési kor: lassan hủlő rendszer (U-Th)/He kora; a He-felhalmozódás a részleges visszatartódási zónában már megkezdődhet. Kevert kor: egy már kihủlt rendszer (U-Th)/He kora, amelyet újbóli felfütés ért, ennek hatására a felhalmozódott He egy része eltávozott a rendszerből

Figure 4. Definition of eruption, cooling and mixed ages in case of zircon (after WAGNER 1979). Eruption age: (U-Th)/He age of a rapidly cooled sample, the accumulation of the He starts at the time of the eruption. Cooling age: (U-Th)/He age of a slowly cooled system, the accumulation of the He starts already in the partial retention zone. Mixed age: (U-Th)/He age of an already cooled system affected by reheating which caused partial He loss from the system 
akkor a kapott cirkon (U-Th)/He-kor „kitörési korként” értelmezhető (4. ábra). Ekkor a He felhalmozódása szempontjából egyedül a felszínre kerülés, vagyis a kitörés pillanata számít, amikor a bomlás során keletkező He elkezdett megőrződni az egyes kristályokban. Amennyiben a vizsgált kôzet lassan húlt le, mint például egy mélységi magmás vagy metamorf kôzettest kiemelkedése esetén, amely lassan halad át a részleges visszatartódás zónán, akkor a kapott (UTh)/He-kor a rendszer „húlési koraként” értelmezhető (4. ábra). Elófordul az is, amikor egy már korábban lehúlt kőzettestet ért utólagos hőhatás. Ekkor a fiatal felfütés mértékétól függ, hogy a rendszer túljut-e a részleges visszatartódás zónáján és a korábban felhalmozódott He teljesen távozik az ásványokból, majd a hôhatást követô újbóli lehưlés következtében kezd el újra felhalmozódni, a felfútési esemény húlési korát megadva ezzel. Amennyiben a hôhatás kisebb és a rendszer hőmérséklete nem jut túl a részleges visszatartódás zónáján, akkor a korábban felhalmozódott He csak egy része távozik a felfütés következtében, és a kapott (U-Th)/He kor nem az utólagos felfútés idejét, hanem egy kevert kort fog megadni, amely több esemény együttes hatását ötvözi (4. ábra). Ezért adott rendszer teljes hôtörténet-ismeretéhez elengedhetetlen több, eltérô záródási hômérséklettel jellemezhetô geokronométer (3. ábra, $B$ ) használata.

\section{Az, „alfa-kilökódési” korrekció ( $F_{T}$-korrekció)}

A kristályban felhalmozódó He mennyiségét a záródási hômérsékleten kívül az alfa kilökődés jelensége is befolyásolja. Ez egy, a rendszer hőmérsékletétôl független folyamat, amely az egyes izotóprendszerekben ${ }^{238} \mathrm{U},{ }^{235} \mathrm{U}$ és ${ }^{232} \mathrm{Th}$ ) lejátszódó alfa bomlások során felszabaduló energiával van összefüggésben. Ugyanis a bomlási sorokban minden egyes anya-, illetve köztes izotóphoz tartozó alfa kilökődésnek van egy karakterisztikus, $\mathrm{MeV}$ nagyságrendú bomlási energiája, amelyhez egy, a befoglaló anyag sưrúségétől függố pályahossz tartozik, amelyet az alfa-részecske befut (ZIEGLER 1977). Ez azt jelenti, hogy az egyes bomlási események térbeli elkülönítést eredményeznek az anya, a leányizotóp, valamint a felszabaduló alfa-részecske $\left({ }^{4} \mathrm{He}\right)$ között (FARLEY et al. 1996). Az egyes bomlási sorok alfa bomlásainak átlagos energiái és alfa-részecskék bomlási sorokhoz tartozó átlagos pályahosszai az I. táblázatban szerepelnek. Ezek az értékek azt jelentik, hogy az adott bomló

I. táblázat. Az egyes bomlási sorok átlagos energiái $(\mathrm{MeV})$ és az a-részecskék átlagos pályahosszai $(\mu \mathrm{m})$ cirkon esetében (FARLEY et al. 1996)

Table I. Average decay energy (MeV) and stopping distances ( $\mu \mathrm{m})$ for zircon (FARLEY et al. 1996)

\begin{tabular}{|l|r|r|}
\hline Bomlási sor & $\begin{array}{c}\alpha \text {-bomlás } \\
\text { energiája } \\
(\mathrm{MeV})\end{array}$ & \multicolumn{1}{|c|}{\begin{tabular}{c}
\multicolumn{1}{c|}{ Átlagos } \\
pályahossz $(\mu \mathrm{m})$
\end{tabular}} \\
\hline${ }^{238} \mathrm{U}$ & 5,36 & 16,65 \\
\hline${ }^{235} \mathrm{U}$ & 5,94 & 19,64 \\
\hline${ }^{232} \mathrm{Th}$ & 5,85 & 19,32 \\
\hline
\end{tabular}

anyaizotóp körül egy 20 ㅆm-es átmérôjú gömb felszínén fog valahol véletlenszerúen megállni a felszabaduló alfarészecske. Ez azt vonja maga után, hogy ha az adott anyaizotóp a kristály külső 20 um-es zónájában vagy a kristály felszínén helyezkedik el, akkor bizonyos valószínúséggel (maximálisan 50\%-kal) kilökődik a felszabaduló ${ }^{4} \mathrm{He}$ a kristályból (5. ábra). Ez a jelenség adott hőmérséklettől

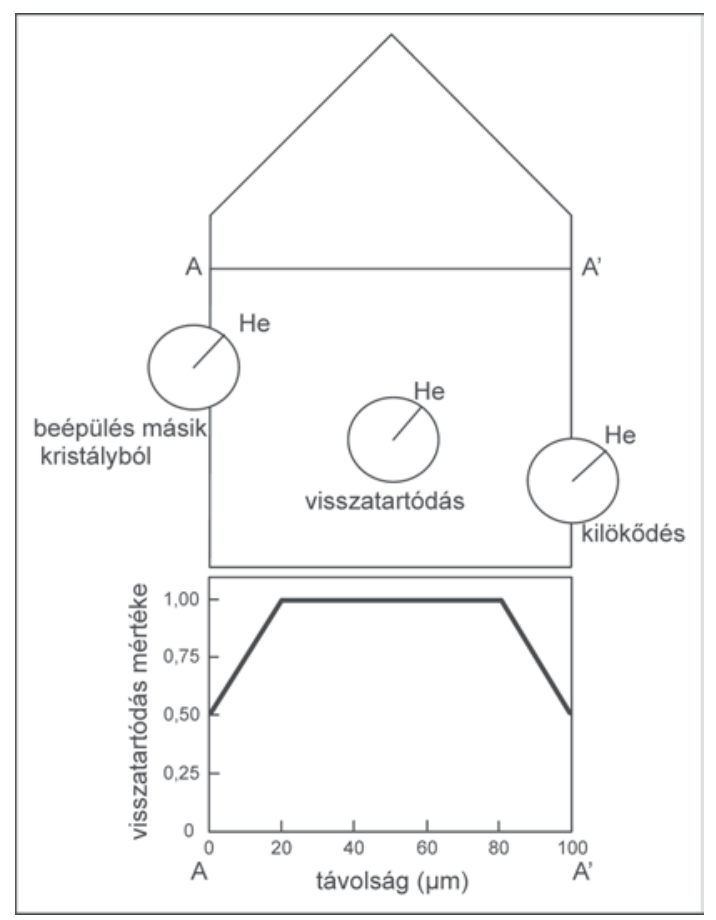

5. ábra. Lehetséges alfa-részecske megállási pozíciók (FARLEY 2002 alapján), a 20 um sugarú körök középpontja a bomlás helyét jelzi, a feltüntetett sugarak pedig a lehetséges utakat, amelyet a felszabaduló He befut

Figure 5. Potential alpha-stopping positions (after FARLEY 2002), the middle of the circles is the position of the decay, while the indicated radii (20 $\mu \mathrm{m}$ long) are possible paths of the released $\mathrm{He}$

függetlenül bekövetkezik, ezért mindig számolni kell vele. A kilökődési veszteség minden kristályt érint, tehát amikor mérjük a jelenkori He-tartalmat, akkor minden esetben kisebb mennyiséget mérünk meg, mint ami ténylegesen keletkezett. Ennek a problémának a megoldására alkották meg az $\mathrm{F}_{\mathrm{T}}$-korrekciót (,,fraction of total”; más néven az alfa-kilökődés korrekciót; FARLEY 2002), amely homogén U- és Theloszlást feltételezve a mért kristály méreteiból, Th/U arányából, valamint a bomlás során keletkezett He mennyiségéből számolja ki a He-visszatartódás mértékét (4. egyenlet), amivel korrigálni kell a nyers koreredményt a valós Hekor meghatározásához:

$$
t=\frac{t^{\prime}}{F_{\mathrm{T}}},
$$

ahol $t$ ' a nyers koradat, $F_{T}$ a He-visszatartódás mértéke, $t$ pedig az $\mathrm{F}_{\mathrm{T}}$-korrigált He-kor (FARLEY 2002). Az $\mathrm{F}_{\mathrm{T}}$-érték egy 0 és 1 közé eső szám, amely közvetetten azt jelzi, hogy a jelenkori mért He-mennyiség mekkora része a tényleges, 
bomlás során keletkezett teljes He mennyiségének. Ennek a kiszámolásához először az adott kristály felszín-térfogat arányának ( $\beta$ ) a kiszámolása (5. egyenlet) szükséges, amely cirkon esetében, tetragonális kristályalakot feltételezve a következő:

$$
\beta\left(L, W_{1}, W_{2}, h\right)=\frac{2\left[\left(W_{1}+W_{2}\right)(L-2 h)+W_{1} \sqrt{h^{2}+\frac{W_{1}^{2}}{4}}+W_{2} \sqrt{h^{2}+\frac{W_{1}^{2}}{4}}\right.}{W_{1} \times W_{2}\left[(L-2 h)+\frac{2 h}{3}\right]},
$$

ahol $L$ a mért kristály hossza, $W_{1}$ és $W_{2}$ a kristály prizmavastagsága, $h$ pedig a kristály piramisának magassága (HoURIGAN et al. 2005). Ezt követi a He visszatartódás mértékének kiszámítása az egyes anyaizotópokra $\left({ }^{238} \mathrm{U}\right.$ és ${ }^{232} \mathrm{Th}$; 6. egyenlet):

$$
{ }^{\mathrm{i}} F_{\mathrm{T}}=1+a_{1} \beta+a_{2} \beta^{2},
$$

ahol $\beta$ felszín-térfogat arány, $a_{1}$ és $a_{2}$ pedig a visszatartódás függvény $3 \mathrm{D}$ modellezéssel meghatározott értékeire illesztett polinom paraméterek, amelyek függnek az izotóprendszertől ( ${ }^{238} \mathrm{U}$ és $\left.{ }^{232} \mathrm{Th}\right)$, a vizsgált ásványtól, valamint a kristályalaktól (II. táblázat; HoURIGAN et al. 2005). Az $i$ jelöli, hogy a mind a ${ }^{238} \mathrm{U}-$, mind a ${ }^{232} \mathrm{Th}$-rendszerre szükséges

II. táblázat. Cirkon esetében az egyes bomlási sorokra meghatározott paraméterek tetragonális kristályalakra (prizma + piramis) (Hourigan et al. 2005)

Table II. Fit parameters in case of zircon, given for tetragonal prism with pyramidal terminations for each decay chains (HoURIGAN et al. 2005)

\begin{tabular}{|l|l|l|}
\hline Bomlási sor & $\mathrm{a}_{1}$ & \multicolumn{1}{c|}{$\mathrm{a}_{2}$} \\
\hline${ }^{238} \mathrm{U}$ & $-4,28$ & 4,37 \\
\hline${ }^{232} \mathrm{Th}$ & $-4,87$ & 5,61 \\
\hline
\end{tabular}

kiszámolni az $\mathrm{F}_{\mathrm{T}}$-faktort. Az utolsó lépés pedig ezekből az átlag $\mathrm{F}_{\mathrm{T}}$ kiszámolása (7. egyenlet):

$$
F_{\mathrm{T}}=a_{238}{ }^{238 \mathrm{U}} F_{\mathrm{T}}+\left(1-a_{238}\right)^{232 \mathrm{Th}} F_{\mathrm{T}},
$$

ahol ${ }^{238 U} F_{T}$ és ${ }^{232 T h} F_{T}$ tehát adott kristályra az egyes bomlási sorokra kiszámolt He-visszatartódás mértéke, az $a_{238}$ pedig a bomlás során keletkezett He részaránya $\left(\mathrm{a}_{238}=(1,04+\right.$ 0,245[Th/U] $)^{-1}$; FARLEY 2002).

A cirkon kristályosodása során olyan kis mennyiségben építi be a ${ }^{235} \mathrm{U}$ és a ${ }^{147} \mathrm{Sm}$ izotópot (FARLEY et al. 2002), hogy az ebből származó He kilökődés okozta veszteség mértéke elhanyagolható, ezért nem szerepelnek a számolásban.

\section{Analitikai eljárás}

Az (U-Th)/He-kor kiszámolásához szükséges az anyaizotópok $\left({ }^{238} \mathrm{U},{ }^{235} \mathrm{U},{ }^{232} \mathrm{Th}\right.$ és $\left.{ }^{147} \mathrm{Sm}\right)$ és ezek bomlásai során felszabadult és megőrződött ${ }^{4} \mathrm{He}$ mennyiségének ismerete. Ezen izotópok megmérése két lépcsőben történik: először az adott kristály ${ }^{4}$ He-tartalmának a mérése zajlik, majd ezt követi az alfa-emittáló elemek mennyiségének meghatározása. Ezen felül meg kell határozni az alfa-kilökődés okozta veszteséget is $\left(\mathrm{F}_{\mathrm{T}}\right)$, ehhez a mért kristály $\mathrm{Th} / \mathrm{U}$ aránya, valamint a méreti- és alaki paramétereinek ismerete szükséges (5. egyenlet; kristályhossz [L], prizmavastagság [ $\mathrm{W}_{1}$ és $\left.\mathrm{W}_{2}\right]$, piramismagasság [h]). Ahhoz, hogy az alfa-kilökődés mértékét ki lehessen számolni, a vizsgált kristálynak az alábbi feltételeknek kell megfelelnie: legyen ép, sajátalakú, repedés- és törésmentes; ne tartalmazzon zárványokat; a kristály alakja a lehető legjobban közelítse a bemutatott egyszerú prizma + piramis modellt; valamint a prizmavastagsága érje el a minimum $\sim 70 \mu \mathrm{m}$-t. Az alaki és méretbeli paraméterek meghatározásához a mérésre gondosan kiválogatott cirkonkristályok tulajdonságainak részletes dokumentálása, valamint mikroszkópi fotózása szükséges.

A ${ }^{4}$ He-tartalom mérése termikus kigázosítással történik, amihez a gondosan kiválogatott cirkon kristályt egy $1 \times 1 \mathrm{~mm}$ nagyságú Pt- vagy Nb-kapszulába kell csomagolni, majd ezt a kapszulát a nemesgáz tömegspektrométerbe, vákuumba helyezni. A hélium felszabadítása hevítéssel történik mikrokemencével vagy infravörös lézerrel. A He mennyiségét egy gáz-tömegspektrométer méri. Minden becsomagolt kristályt legalább kétszer kell kihevíteni, így ellenőrizhetô le, hogy valóban a teljes He-mennyiség eltávozott a mért kristályból. Amennyiben a második hevítés során detektált gáz-felszabadulás aránya meghaladja az első felfútés értékének az 3\%-át, akkor további felfütési lépések alkalmazása szükséges az adott szemcsén. A He-tartalom pontos meghatározásához ${ }^{3} \mathrm{He}$ belső referencia gáz (,spike”) kerül alkalmazásra, ami lehetővé teszi a tömegspektrométer érzékenységének időbeli fluktuációja kompenzálását. A mért teljes ${ }^{4} \mathrm{He}$ mennyiség a datált kristályon kívül a múszer saját héliumtartalmából, a ${ }^{3} \mathrm{He}$ referencia mérésére használt gázban levő ${ }^{4} \mathrm{He}$-ból, valamint a Pt- vagy Nb-kapszulából felszabaduló ${ }^{4} \mathrm{He}$ mennyiségéből adódik össze. A háttér ${ }^{4} \mathrm{He}-$ mennyiséget le kell vonni a teljes értékből, hogy a vizsgált kristály pontos ${ }^{4} \mathrm{He}$-tartalmát megkapjuk.

A kristály anyaizotópjainak a mérése ICP-MS múszerrel történik. Ehhez a kigázosított kristályt ki kell csomagolni a kapszulából, majd oldatba vinni a méréshez. A cirkonkristályok feloldása 5 napon keresztül, $\sim 220{ }^{\circ} \mathrm{C}$-on, teflon bombában, nyomás alatt, 48\%-os HF és 65\%-os $\mathrm{HNO}_{3}$ keveréke segítségével zajlik. Az oldathoz ismert mennyiségű ${ }^{230} \mathrm{Th}$ és ${ }^{233} \mathrm{U}$ spike-ot adunk, hogy az anyaizotópok pontos mennyisége meghatározható legyen. Ezek az izotópok a természetes mintákban csak elhanyagolható mennyiségben fordulnak elő, ezért alkalmazhatók spike-ként. Egy-egy mérési ciklus során több, különböző összetételú, de ismert koncentrációjú oldatot is mérünk, amely egyrészt segíti - a mért oldatokhoz adott ${ }^{230}$ Th és ${ }^{233} \mathrm{U}$ spike mellett — az anyaizotópok mennyiségének pontos meghatározását, másrészt monitorozza a múszer érzékenységét. $\mathrm{Az}{ }^{238} \mathrm{U}$ és ${ }^{232} \mathrm{Th}$ mennyiségét izotóphigításos-, míg a ${ }^{147} \mathrm{Sm}$ koncentrációt külsố sztenderdizációs eljárással mérjük, a ${ }^{235} \mathrm{U}$ mennyiséget pedig a jelenkori ${ }^{235} \mathrm{U} /{ }^{238} \mathrm{U}$ arányból számoljuk ki. Az így kapott ${ }^{4} \mathrm{He},{ }^{238} \mathrm{U},{ }^{235} \mathrm{U},{ }^{232} \mathrm{Th}$ és ${ }^{147} \mathrm{Sm}$ mennyiségekből az (U-Th)/He-kor a Taylor expanziós módszerrel számolható ki (BRAUn et al. 2012). 


\section{Adatértékelés, statisztika}

Az egyedi kristályokon mért korok bizonytalansága lényegében három forrásból származik.

(i) A teljes analitikai bizonytalanság (TAU): az U-, Th-, Sm- és He-mérések egyedi bizonytalanságaiból adódik össze. Az ICPMS és a gáz-tömegspektrométer analitikai bizonytalansága az egyes mért referenciaanyagok (ismert összetételú, koncentrációjú oldatok, valamint az ismert mennyiségű ${ }^{3} \mathrm{He}$ ) segítségével ismerhető meg. Ezekből az egyedi bizonytalansági értékekből négyzetes hibaterjedés (error propagation) segítségével számolható a teljes analitikai bizonytalanság. Ez a módszer teljes bizonytalanságának kis részét alkotja csupán, áltagosan 2-3\%-ot tesz ki. Az egyes mérések bizonytalanságai a ${ }^{4} \mathrm{He}-\mathrm{ra} 1 \%$ körüli, az aktinida elemekre $1-2 \%$, míg a ${ }^{147} \mathrm{Sm}$-ra ennél jóval nagyobb, akár 20-30\% körüli értékeket is adhatnak. Azonban ez utóbbi kapcsán meg kell jegyezni, hogy ezek a nagy bizonytalansági értékek nem rontják le a mérés pontosságát, mivel a ${ }^{147} \mathrm{Sm}$ csak kis mértékben járul hozzá a teljes Hetartalomhoz cirkon datálása esetén.

(ii) Az alfa-kilökődési korrekció $\left(\mathrm{F}_{\mathrm{T}}\right)$ bizonytalansága: a kristály méretének meghatározása és az U-Th mérés bizonytalanságából adódik össze, valamint abból, hogy a valódi kristályalak mennyiben tér el az $\mathrm{F}_{\mathrm{T}}$-korrekció során használt elméleti geometriai modelltôl. Ennek a meghatározása eltérô a kutatók között, mi a következő képeltet használtuk: $\mathrm{F}_{\mathrm{T}}$ hiba $=30 \times\left(1-\mathrm{F}_{\mathrm{T}}\right)$, amely a gyakorlatban azt jelenti, hogy minél kisebb a mérésre kiválasztott kristály, annál nagyobb a hozzátartozó bizonytalanság (4-7. egyenlet).

(iii) A datált kristály nem ideális felépítéséből származó bizonytalanság, amelyet „kristálytani hibának” nevezhetünk. Ennek mértéke nem ismert, azonban hatása jelentôs, amely főleg a radioaktív elemek zónás, szabálytalan elhelyezkedéséból, mikrozárványok és repedések által okozott zavarokból, a szomszédos kristályokból beépült héliumból és a metamiktizáció kristályrácsot romboló hatásából ered (FitzGERAld et al. 2006).

Ezek a hibák együttesen hozzák létre az egyedi kristályokon mért korok bizonytalanságát, amely ideális esetben nem haladja meg a 10\%-ot (pl.: SCHMITT et al. 2010, DANIŠíK et al. 2012, LiNDSAY et al. 2013, HARANGI et al. 2015a).

Egy laboratórium méréseit esetlegesen befolyásoló szisztematikus hiba felléptét ismert korú referenciaanyagok (kor sztenderdek) ismételt méréseivel lehet ellenórizni. A mérések során két leggyakrabban használt referenciaanyag a Durango apatit és a Fish Canyon Tuff cirkon, amelyek más módszerekkel (Ar-Ar, U-Pb) meghatározott kora 31,02 \pm $0,22 \mathrm{Ma}$ (Durango apatit; McDowell et al. 2005) és 28,01 \pm $0,04 \mathrm{Ma}$ (Fish Canyon Tuff cirkon; Phillips \& Matchan 2013).

Általában 3-8 kristály kerül megmérésre egy mintából, amelynek (U-Th)/He-korát a mintába tartozó egyedi mérési eredmények súlyozott vagy súlyozatlan átlaga adja meg. Az átlagszámítás előtt az esetenként megjelenô kiugró kort adó kristályok analitikai adatait át kell tanulmányozni, és ha a mért alfa-emittáló elem és/vagy a hélium mennyisége a kimutatási határhoz közeli, akkor a kristály kihagyható az átlagszámításból. Adott múszer izotóponként eltérő kimutatási határai az egyes laboratóriumokban különbözők lehetnek, a göttingeni Georg-August Egyetem Göochron Laboratóriumában ezek az értékek ${ }^{4} \mathrm{He}-\mathrm{ra} \sim 0,0005$ ncc, ${ }^{238} \mathrm{U}-\mathrm{ra}<1 \mathrm{pg},{ }^{232} \mathrm{Th}$ pedig $<5 \mathrm{pg}$ voltak a 2016. év mérései során (http://www.sediment.uni-goettingen.de/thermochron/ index.html). Ezen felül a kiugró értékek megjelenésének ásványtani okai is lehetnek, amelyek alatt a zárványok jelenléte, az adott kristály U-Th zónássága, illetve a nem ideális kristályalak értendô. Vulkánkitörés korának meghatározásakor az a kezdeti feltételezés, hogy minden kristály geológiai skálán nézve egy időben, a kitörés pillanatában került a záródási hőmérséklet alá, ezért egy kis szórású, normál eloszlású adatsor az elvárás. Azonban fontos megjegyezni, hogy robbanásos kitörési termékekben előfordulhatnak kevert kristálypopulációk is, ugyanis a korábbi kitörésekből származó kristályok belekeveredhetnek a piroklaszt-üledékbe. Az ennek következtében megjelenô idôsebb kristályok felismerése alapvetố fontosságú az adatok értelmezésében a vulkánkitörés korának meghatározásához (pl. HARANGI et al. 2015a).

\section{A módszer továbbfejlesztési lehetôségei}

\section{A kilökódési korrekció bizonytalanságának csökkentése}

A rutinszerú (U-Th)/He mérések során az $\mathrm{F}_{\mathrm{T}}$-korrekció bizonytalansága az eredmények egyik legjelentôsebb hibaforrása - amely az esetenként megjelenő nagy szórású adatsorokban mutatkozik meg. Ugyanis a korrekció alapfeltételezése a kristályon belüli homogén U-Th eloszlás (FARLEY 2002), amely azonban az esetek többségében nem valósul meg (ReINERS et al. 2004). Kimutatták ugyan, hogy a leggyakrabban megjelenô, finom léptékú oszcillációs zónásság nincs módosító hatással az eredményre, azonban, ha a maghoz képest egy U-gazdag vagy egy U-szegény perem található az adott kristályban, akkor a tényleges korhoz képest akár 33\%-os is lehet az eltérés a képződmény valós He-korához képest (6. ábra; MeEsters \& DunAI 2002a, b; TAGAmi et al. 2003). Ennek a problémának az orvoslására tettek kísérletet HouRIGAN és munkatársai (2005), megalkotva az $\mathrm{F}_{\mathrm{ZAC}}$ korrekciós faktort, amely már figyelembe veszi a zónásság hatását is a He-visszatartódás mértékének megállapításához. Munkájukban LA-ICP-MS mérések, 3D modellezés és Monte Carlo-szimulációk segítségével modellezték, hogy a különbözó mértékú mag-perem zónásságokhoz milyen $\mathrm{F}_{\mathrm{ZAC}}$-értékek kapcsolódhatnak, és hogy ezek a különböző típusú zónásságok milyen mértékú eltérést okozhatnak a homogén feltételezéshez képest (6. ábra). Míg HouRIGAn és munkatársai (2005) munkája inkább elméleti jellegú, amely főleg modellszámításokon alapszik, BARGNESI és munkatársai (2016) kísérletet tettek arra, hogy a kristály U-Th zónásság hatásának vizsgálatát átültessék a gyakorlatba is. Az egyik alkalmazott módszer 


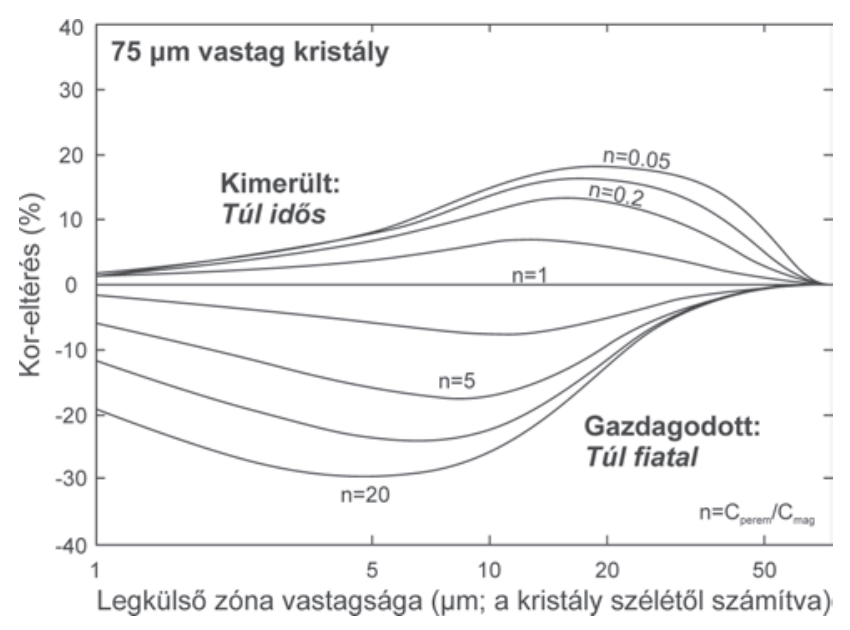

6. ábra. Egy 75 mm-es prizmavastagságú kristály esetében a zónásság okozta koreltérés $(\%)$ a tényleges és a mért korok között, a legkülső zóna vastagságának a függvényében. $\mathrm{Az}$ „n” értékek jelzik a kristály perem/mag koncentrációarányát, ahol $\mathrm{n}>1$ gazdagodott-, míg $\mathrm{n}<1$ kimerült legkülső zónát jelöl (HouRIGAN et al. 2005 alapján)

Figure 6. He age bias plots for $75 \mu \mathrm{m}$ model crystal with rims of variable thickness and degree of enrichment $(n>1)$ or depletion ( $n<1$; after HouRIGAN et al. 2005)

erre a mechanikai abrázió volt, amelynek segítségével eltávolították a kristály külső, 30 بm-es zónáját. Ennek előnye, hogy így sem a He-kilökődés okozta veszteséggel (tehát $\mathrm{F}_{\mathrm{T}}=1$ ), sem a külső zóna U(-Th) gazdagodása/szegényedése okozta hatással nem kell számolni, hátránya azonban az, hogy egy jóval kisebb térfogú kristálydarab kerül csak mérésre. A másik módszer a kristály prizmáján végzett lyukfúrás LA-ICPMS múszerrel, amely során adott pontban átlagosan 40-45 $\mu$ m mélységig kaptak információt az Ués Th-tartalomról, és ebből modellezték Monte Carloszimuláció segítségével az U-Th eloszlást a teljes kristályra. Munkájuk hozzájárul ahhoz, hogy a rutinszerú (U-Th)/He mérések gyakorlatába is egyre inkább beépítsék ezeket a plusz-lépéseket, amelyekkel a mért kristály zónásságát pontosabban meg lehet ismerni, és ennek figyelembevételével jobb, kisebb szórású eredményeket lehet kapni.

\section{In situ hélium geokronológia}

Míg a „klasszikus” (U-Th)/He geokronológia alkalmazásakor az egész kristály hélium- és radioaktív izotóp tartalma kerül meghatározásra, az in situ technika esetében csak a kristály egy kis térfogatából távolítják el az anyagot egy excimer lézer segítségével a hélium mennyiségének meghatározásához, majd ugyanazon a ponton megmérik az U+Th tartalmát is LA-ICP-MS múszer használatával (pl.: TRIPATHY-LANG et al. 2013, EvANS et al. 2015). Felpolírozott szemcséken zajlik a mérés, így lehetséges előzetesen katódlumineszcens képeket is készíteni a vizsgált kristályokról, ezáltal megismerhetővé válik a belső felépítése a datált kristálynak. Nagy előnye a módszernek, hogy lényegesen gyorsabb a „,klasszikus” (U-Th)/He eljárásnál, a mérés során nem kell veszélyes savakat használni, valamint a pontszerú mérésből adódóan nem kell számolni az alfa-kilökődés okozta veszteséggel (ha a mérési pont a kristály peremétől legalább $20 \mu \mathrm{m}$-re van). Az in situ módszer ezen felül lehetôvé teszi a „dupla datálást” is, vagyis lehetséges akár egy kristály ugyanazon pontján U-Pb kort (=kristályosodás) és He kort (=húlés) is mérni (Evans et al. 2015). Ennek különösen a sziliciklasztos üledékek származáselemzésénél van nagy jelentősége. Hátránya az in situ eljárásnak, hogy a megmért anyag kis mennyiségéből következően a mérési adatok bizonytalansága, szórása jóval nagyobb, mint a konvencionális módszernél megszokott értékek (TRIPATHYLANG et al. 2013). Továbbá fiatal, tehát kis He-tartalmú minták mérése esetén gondot okozhat az, hogy nem a teljes kristály kigázosítása történik meg, hanem csak egy jóval kisebb térfogat He-tartalmát méri, amely jó eséllyel a múszer kimutatási határánál kevesebb ${ }^{4} \mathrm{He}$-ot tartalmaz.

\section{A szekuláris egyensúly kérdése}

Az (U-Th)/He módszer alapegyenletének (1.) legfontosabb feltétele a szekuláris egyensúly megléte a radioaktív bomlási soron belül. Szekuláris egyensúlynak nevezzük azt az állapotot, amikor az adott anya- és a hozzátartozó leányizotóp aktivitásának (tehát az egységnyi idő alatt történő bomlásaiknak száma, vagyis $\mathrm{N}_{\mathrm{i}} \times \lambda_{\mathrm{i}}$, ahol $\mathrm{N}$ az atomok száma, $\lambda$ pedig az adott izotóp (i) bomlási állandója) az aránya 1 (BATEMAn 1910). Azonban adott, (U-Th)/He mérésre alkalmas ásványok (pl.: cirkon, titanit) kristályosodásukkor frakcionálhatják az egyes izotópokat, amelynek következtében a bomlási sorokban szereplő köztes izotópokat (pl. ${ }^{230} \mathrm{Th},{ }^{231} \mathrm{~Pa},{ }^{226} \mathrm{Ra} ; 1$. ábra) is beépíthetnek a kristályrácsukba (pl. DosseTo \& TURNER 2010). Ez adott bomlási soron izotóphiányt, illetve -többletet okoz, aminek hatása megmutatkozik a keletkező He mennyiségében is, az eredeti egyenletben (1.) szereplő szorzók (8, 7, 6, illetve 1) nem a valós állapotot fogják tükrözni (FARLEY et al. 2002). Ez az izotóphiány, illetve -többlet azt okozza, hogy adott anya- és hozzátartozó leányizotóp egységnyi idő alatt történô bomlásaik számának az aránya nem 1 lesz, tehát az adott bomlási soron belül szekuláris nem egyensúlyi állapot fog uralkodni (FARLEY et al. 2002). A kezdeti feltételektől függetlenül, a kristályosodást követôen a szekuláris egyensúly beállta csak a leghosszabb felezési idővel rendelkező frakcionálódó köztes izotóp felezési idejének kb. 5-szöröse eltelte után történik meg (FARLEY et al. 2002; 7. ábra). Azt kell tehát megvizsgálnunk a szekuláris egyensúly kérdésének körüljárásakor, hogy melyek azok az izotópok, amelyek magmás körülmények között, a cirkon kristályosodásakor frakcionálódnak, és ezek közül melyek azok, amelyeknek felezési ideje olyan nagy, hogy geológiai időskálán nézve már befolyással lehetnek a szekuláris egyensúlyra. $\mathrm{A}^{238} \mathrm{U}$ sor esetében a legnagyobb felezési idővel rendelkező izotóp $\mathrm{a}{ }^{234} \mathrm{U}\left(\mathrm{t}_{1 / 2}=245\right.$ ezer év; CHENG et al. 2000; 7. ábra — piros szaggatott vonal), amely azonban magmás körülmények között elhanyagolható mértékben frakcionálódik (pl.: REID et al. 1997), így nincs befolyással az egyensúlyra. A következő nagy felezési idejű köztes leányizotóp a ${ }^{230} \mathrm{Th}\left(\mathrm{t}_{1 / 2}=75\right.$ ezer év; 7. ábra — zöld szaggatott vonal), amely jelentôs 


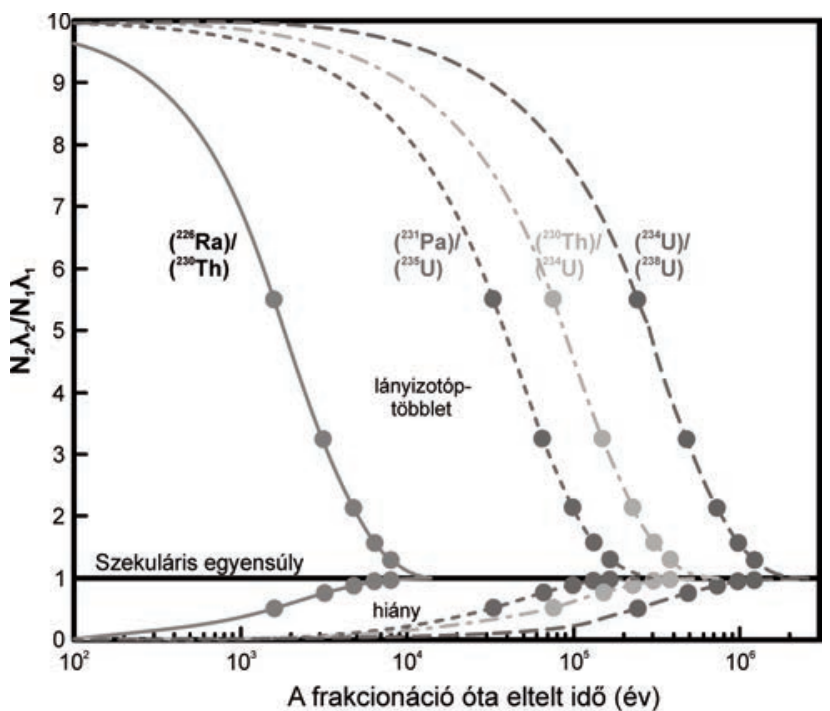

7. ábra. A bomlási sorok szomszédos tagjainak aktivitásarány változása a frakcionáció (vagyis a kristályosodás) óta eltelt idő függvényében (SCHMITT 2011 alapján)

Figure 7. Activity ratios for intermediate daughter and parent isotope pairs as a function of time after the fractionation event (i.e. after the time of crystallization; after SCHMITT 2011)

mértékben frakcionálódik cirkon kristályosodása esetén (pl. BOURDON et al. 1994, ReID et al. 1997, CHARLIER \& ZELLMER 2000). Így a ${ }^{238} \mathrm{U}$ bomlási sorban a szekuláris egyensúly beállása a bomlás megindulását — tehát a cirkon kristályosodást — követően 380 ezer év után történik meg a ${ }^{230}$ Thra nézve (SCHMITT 2011). Ugyanezen bomlási soron belül még a ${ }^{226}$ Ra izotóp ( $\mathrm{t}_{1 / 2}=1,6$ ezer év; FABBRIzIO et al. 2008; 7. ábra) frakcionálódása lehet jelentős, azonban kis felezési ideje miatt ennek a hatásával csak 8 ezer évnél fiatalabb minták esetében kell számolni. A ${ }^{235} \mathrm{U}$ bomlási soron belül elméletileg hatással lehetne a szekuláris egyensúlyra a ${ }^{231} \mathrm{~Pa}$ izotóp ( $\mathrm{t}_{1 / 2}=33$ ezer év; ROBERT et al. 1969; 7. ábra) frakcionálódása, azonban a ${ }^{235} \mathrm{U}$ részaránya annyira kicsi (1/137,818-ad része a ${ }^{238} \mathrm{U}$-nak), hogy még az esetleges nemegyensúlyi állapot fennállása sincs befolyással a He-rendszerre (FARLEY et al. 2002). A ${ }^{232}$ Th jelentős mennyiségben épül be a kristályrácsba a cirkonkristályosodáskor, azonban ebben a bomlási sorban nem található olyan köztes leányizotóp, amelynek felezési ideje meghaladná a 7 évet, így itt minden esetben fennállónak tekinthetjük a szekuláris egyensúlyi állapotot (FARLEY et al. 2002). A ${ }^{147}$ Sm esetében pedig csak egy $\alpha$-bomlási esemény történik, így itt nem értelmezhető a köztes leányizotópok frakcionálódása.

A szekuláris egyensúlyra cirkon esetében tehát a kristályosodáskor történő ${ }^{230} \mathrm{Th}$ izotóp frakcionálódása van befolyással. Ez azt jelenti, hogy kristályosodáskor ${ }^{230} \mathrm{Th}$ is beépül a kristályrácsba (pl. REID et al. 1997), amely Hehiányt okoz a rendszerben abban az esetben, ha a vizsgált minta (1) 380 ezer évnél fiatalabb, vagy (2) a He-felhalmozódás kezdete és a kristályosodás ideje között nem telt el legalább 380 ezer év. Amennyiben ilyen minták esetében az egyensúlyt feltételező egyenletet (1.) használjuk az (UTh)/He kor kiszámolásához, akkor a frakcionáció okozta He-hiány miatt alulbecsüljük a minta valós korát (8. ábra).

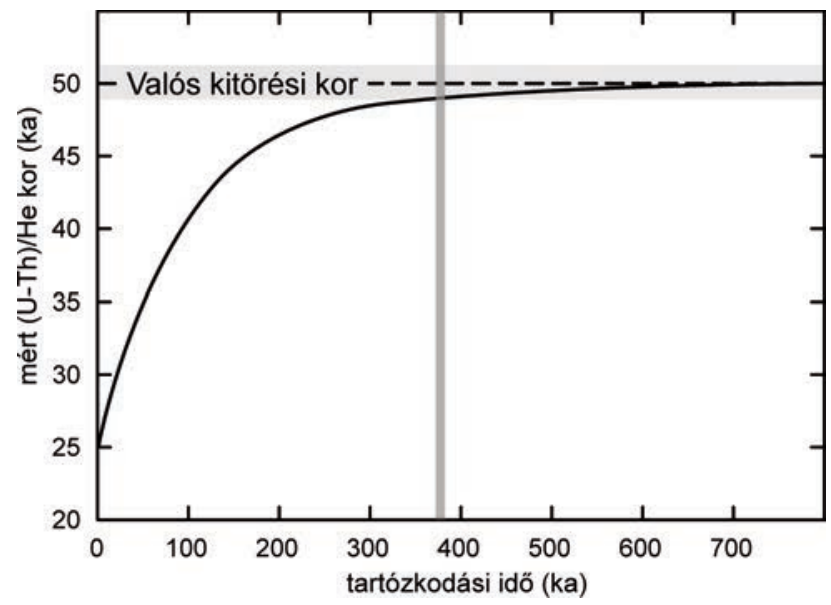

8. ábra. A cirkon magmakamrában való tartózkodási idejének hatása (x tengely) az (U- Th)/He korra (DANIŠík et al. 2016 alapján). Az y tengelyen az egyensúlyt feltételező mért (U-Th)/He kor szerepel, a frakcionáció okozta Hehiányt jelzi a mért és a valós kor közötti eltérés, amely akkor a legnagyobb, ha a tartózkodási idő 0 (=teljes nem egyensúlyi állapot). Minél jobban közelít a tartózkodási idő a szekuláris egyensúly beállásához szükséges kb. 380 ezer évhez (piros vonal), annál kisebb lesz az eltérés a mért és a valós kor között

Figure 8. The effect of magma residence time (x axis) on the zircon $(U-T h) / H e$ age (after DANIŠ́K et al. 2016). The difference between the measured (U-Th)/He age ( $y$ axis) and the true eruption age is because of the He deficit caused by the effect of fractionation. The shorter the magma residence time is, the larger the underestimation is, while the closer the residence time to the $\sim 380 \mathrm{kyrs}$ (red line) is, the smaller the difference is

Azt az esetet, amikor a rendszer közvetlenül a cirkon kristályosodását követően a záródási hőmérséklet (150$180{ }^{\circ} \mathrm{C}$ ) alá húl, tehát amikor cirkon kristályosodását követően rögtön megkezdődik a bomlás során keletkező He felhalmozódása, teljes nem-egyensúlyi állapotnak nevezzük. Az ekkor keletkező és az ásványban felhalmozódó He teljes mennyiségét a következő (8.) egyenlet írja le, amely már számol a kristályosodáskor történő ${ }^{230}$ Th beépülésének a lehetôségével is (zéró kezdeti héliummal számolva; FARLEY et al. 2002):

$$
\begin{gathered}
{ }^{4} H e_{\text {diseq }}=6 \times\left({ }^{232} T h /{ }^{238} U\right)^{238} U \lambda_{232} t+ \\
(7 / 137,818) \times{ }^{238} U \lambda_{235} t \\
{ }_{238} t+6 \times \lambda_{238} \times{ }^{238} U\left(1-e^{-\lambda 230 t}\right)\left(D_{230}-1\right)+ \\
1 \times{ }^{147} S m \lambda_{147} t,
\end{gathered}
$$

ahol az eredeti (1.), egyensúlyt feltételező egyenlethez képest az új tagok a $\lambda_{230}, \mathrm{a}^{230}$ Th bomlási állandója $(9,1705 \times$ $10^{-6} \mathrm{é}^{-1}$ ), a $D_{230}$ pedig a kezdeti (a cirkon kristályosodásakor fennálló) ${ }^{230} \mathrm{Th} /{ }^{238} \mathrm{U}$ aktivitás arány. Ez utóbbi alapból egy ismeretlen érték lenne, mivel azonban a ${ }^{230} \mathrm{Th} /{ }^{232} \mathrm{Th}$ nem frakcionálódik, ezért lényegében a kezdeti ${ }^{232} \mathrm{Th} /{ }^{238} \mathrm{U}$ aktivitásarány megegyezik a ${ }^{230} \mathrm{Th} /{ }^{238} \mathrm{U}$ aránnyal, és a következőképp számolható ki (9. egyenlet: FARLEY et al. 2002):

$$
D_{230}=\left({ }^{232} T h /{ }^{238} U\right)_{\text {kristaly }} /\left({ }^{232} T h /{ }^{238} U\right)_{\text {magma }},
$$

ahol a magma ${ }^{232} \mathrm{Th} /{ }^{238} \mathrm{U}$ arányát az adott minta teljes kőzetvagy üveg ${ }^{232} \mathrm{Th} /{ }^{238} \mathrm{U}$ aránya adja meg. A teljes nem egyen- 
súlyi állapotot leíró egyenlet (8.) figyelembe veszi a cirkon kristályosodáskor történo ${ }^{230} \mathrm{Th}$ frakcionálódás hatását a teljes He-mennyiségre. Külön kezeli a kristályba beépülő ${ }^{238} \mathrm{U}$ izotóp egyensúlyi körülmények között végbemenó bomlása során keletkező ${ }^{4} \mathrm{He}-\mathrm{t}$ (3. sor, 1. tag), a ${ }^{238} \mathrm{U}$ bomlása során keletkező ${ }^{230}$ Th bomlásából származó ${ }^{4} \mathrm{He}$ mennyiségét (3. sor, 2. tag), valamint a kristályosodáskor a frakcionáció következtében beépülő ${ }^{230} \mathrm{Th}$ bomlása során felszabaduló ${ }^{4} \mathrm{He}-\mathrm{t}$ (3. sor, 3. tag).

A teljes nem egyensúlyi állapotot leíró egyenlet segítségével tehát kiszámolható, hogy mi lenne a vizsgált minta (U-Th)/He kora abban az esetben, ha a minta közvetlenül a cirkonkristályosodást követôen a záródási hômérséklet alá húlne, tehát rögtön megkezdődne a He felhalmozódása az egyes kristályokban. Ez a gyakorlatban akkor fordulhat eló, ha a cirkon kristályosodásával közel egy időben megtörténik a vulkánkitörés is, tehát a cirkon tartózkodási ideje a magmakamrában 0. Azonban ismert, hogy a legtöbb magmás rendszer esetében nem teljesül az, hogy a kitörés rögtön a cirkon kristályosodását követően bekövetkezik, hanem minden esetben kell valamekkora tartózkodási idővel számolni (pl.: ReID 2008, KLemetti \& ClynNe 2014), ami elősegíti az egyensúly valamilyen mértékú beállását. Minél több idôt tölt egy adott cirkonkristály a kitörést megelőzően a magmakamrában, annál közelebb kerül a rendszer az egyensúlyi állapothoz, és annál kisebb hatással van az (UTh)/He eredményre a nem egyensúlyi állapot okozta eltérés (8. ábra). Minden minta esetében szükséges lenne annak vizsgálata, hogy adott cirkon kristályosodása és a He-felhalmozódás kezdete között mennyi idő telt el, azért, hogy megállapíthassuk, beállt-e a bomlási sorban a szekuláris egyensúly a kitörés előtt, illetve ha nem, akkor milyen mértékben került egyensúlyba. Azonban a gyakorlat azt mutatja, hogy 1 millió évnél idősebb minták esetében kisebb az esetleges nem egyensúlyi állapot okozta eltérés (FARLEY et al. 2002), mint az (U-Th)/He kronométer módszertani/technikai bizonytalansága. Ezért csupán a fiatal $(<1$ millió év) vulkánkitörések korának meghatározásánál kell számolni a cirkon kristályosodásakor fellépo ${ }^{230} \mathrm{Th}$-frakcionáció okozta nem egyensúlyi állapot meglétével. Erre az egyik lehetôség, hogy az egyensúlyt feltételező egyenlet (1.) segítségével meghatározott (U-Th)/He kor mellett kiszámoljuk a teljes nem egyensúlyi állapotból adódó (U-Th)/He kort is (8. egyenlet). Ebben az esetben a vulkánkitörés idejére egy intervallumot kapunk, amelynek alsó és felső határát az egyensúlyi (minimum kor) és a teljes nem egyensúlyi (maximum kor) He kor jelöli ki. A másik opció, hogy a minta egyensúlyi (U-Th)/He kora mellett a vizsgált cirkonkristály képződési korát is meghatározzuk. A két kor — kitörési és kristályosodási - ismeretében megállapítható, hogy mekkora volt a magmakamrában eltöltött idő, tehát adott kristály a kitörés pillanatában milyen mértékben került egyensúlyba. Ebből lehet következtetni arra, hogy mekkora He-hiánnyal kell számolni a rendszerben, amivel az egyensúlyt feltételező (U-Th)/He kort korrigálni kell, hogy a valós kitörési kort megkapjuk. A kristályosodási kor meghatározása
380 ezer évnél fiatalabb képződmények esetében az U-Th vagy U-Pb, míg az ennél idôsebb mintáknál csak az U-Pb kormeghatározási módszerrel, SIMS vagy LA-ICPMS múszer segítségével lehetséges. A mérések vagy kiválogatott cirkonkristály felszínén, vagy pedig beágyazott, majd felpolírozott kristályokon történnek (SchMitT 2011). Az előbbi módszer alkalmazása során lehetôség nyílik ugyanazon a kristályon elvégezni az (U-Th)/He mérést is ('doubledating'), amelynek nagy előnye, hogy egyszerre ad információt egy kristály utolsó, legfiatalabb kristályosodási idejéről és a He-felhalmozódás kezdetéről, ezáltal pontosan meghatározható, hogy az adott kristály a kitörés pillanatában milyen mértékben került egyensúlyba (pl.: SCHMITT et al. 2010). A másik módszer esetében, amikor felpolírozott kristályokon történik a mérés, lehetőség van arra, hogy egy átfogóbb képet kapjunk a teljes populáció kristályosodási időtartamáról (mettól meddig tart, mikor volt(ak) a fố kristályosodási időszak[ok]), valamint a mérést megelőzốen készült katódlumineszcens képek nemcsak a mérési pontok kijelölésében, hanem a minta cirkonpopulációjának részletesebb jellemzésében is segítséget nyújtanak (pl. DANIŠíK et al. 2012, HARANGI et al. 2015a). A két módszer között a választás függ az aktuális mintától, valamint a rendelkezésre álló mérési lehetőségektől, természetesen a legideálisabb minden esetben a kettő együttes alkalmazása lenne.

SchмiтT és munkatársai (2010) ismertették azt az O. M. LOVERA által írt szabad hozzáférésú programot (MCHeCalc; http://sims.ess.ucla.edu/Research/MCHeCalc.php), amelynek segítségével modellezhetố a nem-egyensúlyi (UTh)/He kor egy adott ásványpopuláció egyedi kristályaira, valamint a teljes populációra is. A program bemeneti adatai: (1) a populáció egyedi kristályainak (U-Th)/He kora (szekuláris egyensúlyt feltételezve) + az egyes korok $1 \sigma$ bizonytalansága, (2) az egyedi kristályokra vonatkozó $\mathrm{D}_{230}$ értéke és (3) az egyedi kristályok/kristálypopuláció kristályosodási kora (U-Th vagy U-Pb), valamint $1 \sigma$ bizonytalansága. Ezeket felhasználva számolja ki Monte Carlo-szimulációk segítségével a program a populáció egyedi kristályaira az egyes korrigált koreloszlásokat (valószínúségi sürúségfüggvényeket), amelyek metszéspontjai jelölik ki a teljes populációra vonatkozó nem egyensúlyi He koreloszlást. Ez a teljes populációra modellezett koreloszlás jellemezhetô az eloszlásgörbe maximumával (eloszlásgörbe csúcsa), amely megadja a populáció korrigált, nem egyensúlyi (U-Th)/Hekorát, valamint a görbe alakjával (lefutásával), amely pedig az eredmény bizonytalanságát adja meg. Ezeken felül a program számol egy ún. ,goodness of fit” (az illesztés jósága) paramétert is, amely a kapott egyedi koreloszlások és a teljes populációra vonatkozó koreloszlás közötti eltérés vizsgálatán alapul, aminek segítségével lehet következtetni a kapott eredmény helyességére. Amennyiben ez az érték nagyobb, mint 0,001 (PRESS et al. 2002), akkor a számított értékek elfogadhatók. A MCHeCalc program képes modellezni adott populációra a teljes nem egyensúlyi (U-Th)/He kort is, aminek akkor van nagy jelentősége, ha nem ismerjük az egyedi kristályok kristályosodási korait.

A továbbiakban általunk mért mintákon kerül bemuta- 
tásra a módszer gyakorlati alkalmazása fiatal ( $<1$ millió év) vulkánkitörések esetében.

\section{Esettanulmányok}

A Kárpát-Pannon térséget szilíciumgazdag , mészalkáli, alkáli bazaltos és káli-ultrakáli vulkanizmus jellemezte az elmúlt 20 millió évben (SZABÓ et al. 1992; LEXA \& KONEČNÝ 1974, 1998; HARANGI 2001; KONEČNÝ et al. 2002; SEGHEDI et al. 2004, 2005; PÉCSKAY et al. 2006; HARANGI \& LENKEY 2007; SEGHEDI \& Downes 2011). A változatos jellegú vulkáni múködés kialakulása szorosan kapcsolódott a térség összetett geodinamikai fejlődéséhez (pl.: RoYDEN et al. 1983, Csontos et al. 1992, HoRvÁTH 1993, HoRvÁTH et al. 2006). A kvarter (<2,6 M év) során a vulkáni aktivitás fooleg a régió peremi területeire koncentrálódott, változatos jellege azonban továbbra is megmaradt. A szilíciumgazdag, riolitos múködés kivételével mindegyik típushoz kapcsolódtak még vulkánkitörések (PÉCSKAY et al. 2006, HARANGI \& LENKEY
KARÁTSON et al. 2013, 2016; SZAKÁCS et al. 2015). A tűzhányó, amelynek legutolsó kitörése 30 ezer évvel ezelőtt következett be (VINKLER et al. 2007; HARANGI et al. 2010, 2015a; KARÁTSON et al. 2016), a Kelemen-GörgényHargita vulkáni ív délkeleti elvégződésénél található. Az ív mentén a vulkáni aktivitás 11,3 millió évvel ezelőtt kezdődött, és egy folyamatos, délkeleti irányú fiatalodás figyelhető meg a múködésében (PÉCSKAY et al. 1995). Ezzel a fiatalodással párhuzamosan a felszínre került magmák térfogatának csökkenése, valamint összetételük változása (a K-tartalom növekedése, gazdagodás inkompatibilis nyomelemekben) mutatható ki (SEGHEDI et al. 1987, SZAKÁCS et al. 1993, MASON et al. 1998). Ez utóbbi azonban nem folyamatosan történt, hanem egy éles váltásként észlelhető 3 millió évvel ezelőtt a Hargitában, szorosan kapcsolódva a térség fő tektonikai zónájához, a Trotusvetôhöz (HARANGI \& LENKEY 2007, SEGHEDI et al. 2011).

A Csomád egy összetett, dácitos lávadóm-komplexum, amely magában foglal egy központi ikerkrátert (Szent Annaés Mohos-kráter). Északi oldalán lávadómok, míg a déli

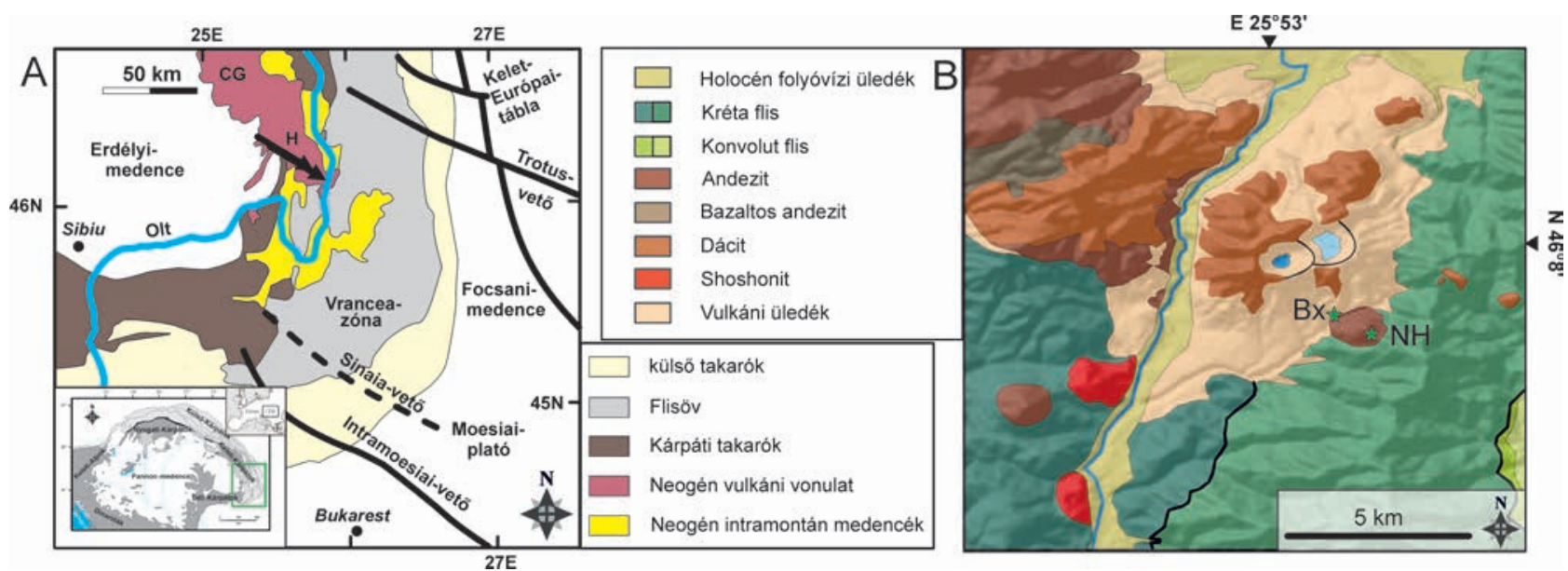

9. ábra. A) A Kelemen-Görgény-Hargita egyszerűsített földtani térképe (HARANGI et al. 2013 alapján); CG: Kelemen-Görgény, H: Hargita; a nyíl jelöli a kinagyított dél-hargitai területet. B) a Dél-Hargita földtani térképe (IANOVICI \& RĂDULESCU; Román Földtani Intézet 1:200 000-es térképlapja (1968) és SzAKÁCS et al. 2015 alapján), feltüntetve rajta a két bemutatott lelöhely mintapontjait (Bx és NH)

Figure 9. A) Simplified geological map of the Călimani-Gurghiu-Harghita volcanic chain (after HARANGI et al. 2013). The arrow indicates the enlarged area of the SouthHarghita B) geological map of the South Harghita with the NH and Bx sampling site (based on the 1:200 000 map by IANOVICI \& RăDULESCU; Geological Institute of Romania and SZAKÁCS et al. 2015)

2007, SEGHEDI et al. 2011). Kutatásunk fókuszában a térség legfiatalabb vulkáni múködéséhez (Csomád, Dél-Hargita, Keleti-Kárpátok; 9. ábra) kapcsolódó kitörési termékek, valamint a túzhányó környezetében megtalálható egyedi lávadómok állnak. A területen régóta folyó kutatások eredményeképp számos információ áll rendelkezésünkre a Csomád és környezete fizikai vulkanológiai (pl.: SzAKÁCS \& SEGHEDI 1986, SZAKÁCS et al. 1993, VINKLER et al. 2007, SZAKÁCS et al. 2015, KARÁTSON et al. 2016), petrogenetikai (pl.: VINKLER et al. 2007, KISS et al. 2014), geofizikai (pl.: SPERNER et al. 2004, PopA et al. 2005, HARANGI et al. 2015b), geodinamikai (pl.: MASON et al. 1998, Cloething et al. 2004, SEGHEDI et al. 2011) és geokronológiai fejlődésérôl, jellemzéséról (pl.: JUVIGNE et al. 1994; MORIYA et al. 1995, 1996; PÉCSKAY et al. 1995; HARANGI et al. 2010, 2015a; lejtőkön a robbanásos kitörésekből származó piroklasztárüledékek dominálnak (9. ábra, B). Környezetében továbbá számos kis méretú, periferális andezites-dácitos lávadóm található, amelyek szintén a Csomádhoz sorolhatók (pl.: SzAKÁCS et al. 2015). A vulkáni múködés kronológiájának különböző módszerekkel (K-Ar, radiokarbon, (U-Th)/He, IRSL, OSL) történô meghatározása már régóta a kutatások középpontjában áll. A tûzhányó környezetében található perifériális dómokat is figyelembe véve az aktivitás 1 millió évvel ezelőtt kezdődött a területen (PÉCSKAY et al. 1995, SzAKÁCs et al. 2015), míg az utolsó, robbanásos fázis 5632 ezer éve zajlott le (HARANGi et al. 2015a). Nehezíti azonban a kitörési kronológia pontos meghatározását, hogy az egyes módszerek sokszor eltérő eredményeket adnak az egy lelőhelyen gyújtött minták esetében. Erre példa a 
tusnádfürdői piroklasztit, amelynél a biotiton mért K-Ar kor 500 ezer évet (PÉCSKAY et al. 1995), míg az ugyanabból a rétegból származó szenesedett növénymaradvány 43 ezer éves kitörési kort adott eredményül (HARANGI et al. 2010). Akadnak azonban pozitív példák is a területról, amikor a különböző módszerek (radiokarbon és (U-Th)/He, illetve IRSL és (U-Th)/He) egymást alátámasztó kitörési korokat adtak eredményül (HARANGI et al. 2010, 2015a).

A Csomád kôzetein végzett (U-Th)/He módszerrel meghatározott kronológiát elsőként, még korrigálatlan koradatokkal KARÁTSON és munkatársai (2013) közölték, majd HARANGI és munkatársai (2015a) rekonstruálták a kitörési időket és a kitörési történetet a legfiatalabb vulkáni fázisra a már nem egyensúlyi állapotra korrigált koradatok alapján. Jelen cikkben két kitörés (9. ábra) példáján mutatjuk be új adatokkal kiegészítve - a módszer alkalmazhatóságát fiatal vulkánkitörések datálására. Ezen a területen az (UTh)/He geokronológia használata több okból is indokolt. A korábbi mérésekből publikált korok (HARANGI et al. 2015a) azt mutatják, hogy pont abban a kritikus időintervallumban történt a kitörések nagy része $(<1$ millió év), amely módszertani korlátok, vagy megfelelő ásványok hiányában más módszerekkel nehezen meghatározható (DANIŠí́ et al. 2016.).

Az egyik példa a Nagy-Hegyes (Dealul Mare) andezites lávadómja (mintanév: $\mathrm{NH}$; 9. ábra, $B$ ), amely egyike a központi lávadóm környezetében található perifériás dómoknak. Korábban meghatározott K-Ar kora 1,02 \pm 0,07 M év (SZAKÁCs et al. 2015). A másik példa pedig a Csomád eddig ismert utolsó kitörése során keletkezett piroklasztár-üledék (mintanév: Bx; 9. ábra, B), amely a központi lávadóm déli lejtôjén található, 3 km-re Sepsibükszád (Bixad) településétôl (VINKLER et al. 2007 — „Bx”; HARANGI et al. 2015a „MK-5”; KARÁTsOn et al. 2016 — „BIX-1”). Az itt végzett kombinált U-Th és (U-Th)/He mérésekből HaRANGi és munkatársai (2015a) a kitörés korát 32,6 \pm 1,0 ezer évre értelmezték (a koradat hibáját 1 szigma bizonytalansággal megadva). Ez összhangban van a feltárásból származó, szenesedett növénymaradványon végzett radiokarbonos kor- meghatározás eredményével (31,230-32,700 cal BP; HARANGI et al. 2010). E képződmény esetében a már publikált eredményeket mutatjuk be az eddigieknél részletesebben, míg a nagy-hegyesi minta esetében új koradatot közlünk. Mindkettő jó példa a cirkon (U-Th)/He módszer alkalmazhatóságára fiatal vulkánkitörések datálására, valamint arra is, hogy milyen hatással van a cirkon kristályosodáskor bekövetkező ${ }^{230} \mathrm{Th}$ frakcionáció az eredményekre fiatal $(<1$ millió év) minták esetén.

A mérések mindegyike a göttingeni Georg-August Egyetem Göochron Laboratóriumában készültek, a mérés körülményei és az adatok feldolgozási módja megegyezik a cikkben bemutatott metódussal (lásd: Analitikai háttér és Adatértékelés, statisztika; illetve HARANGI et al. 2015a). A laboratóriumban a Fish Canyon Tuff cirkon referenciaanyagra kapott kormérések átlaga 28,1 $\pm 0,2$ millió év $(\mathrm{n}=128)$, amely közel esik a PHILLIPS \& MATCHAN (2013) által kapott 28,01 $\pm 0,04$ M év Ar/Ar korhoz.

\section{A Nagy-Hegyes lávadómja}

A nagy-hegyesi andezites mintából 6 cirkonkristályt választottunk ki a minta-előkészítést követően az (U-Th)/He kormérésre. A kiválogatott kristályok méreteit, a kapott mérési adatokat, az ezekből számolt egyedi korokat, valamint ezek súlyozott átlagait és az adatokhoz tartozó bizonytalanságot a III. táblázat, valamint a 10. ábra tartalmazza.

A nyers (korrigálatlan) korok 610 és 725 ezer év közé esnek (10. ábra; nyers (U-Th)/He-korok), ezek az értékek azonban még nem tartalmazzák az $\alpha$-kilökődésből származó He-hiányt, ezért szükséges az alaki $\left(\mathrm{F}_{\mathrm{T}}\right)$ korrekciós számolás az egyedi korokon. A nyers (U-Th)/He korokhoz tartozó bizonytalanságok (III. táblázat; TAU) nem haladják meg a 2,5\%-ot, jól tükrözve az (U-Th)/He módszer analitikai pontosságát és a gáz-tömegspektrométer érzékenységét még ilyen fiatal (He-szegény) minták esetén is. Az egyedi nyers (U-Th)/He korokból számolt $\mathrm{F}_{\mathrm{T}}$-korrigált korok 816 ezer és 879 ezer év közé esnek. Az ezekhez a korokhoz tartozó bizonytalanságok már tartalmazzák az

III. táblázat. A nagy-hegyesi andezites mintából származó cirkon (U-Th)/He eredmények Table III. The zircon (U-Th)He age results of the andesitic NH sample

\begin{tabular}{|c|c|c|c|c|c|c|c|c|c|c|c|c|c|c|c|c|c|c|c|c|c|c|}
\hline \multirow[b]{2}{*}{$\begin{array}{l}\text { Minta- } \\
\text { név }\end{array}$} & \multirow[b]{2}{*}{$\begin{array}{l}\text { Teljes } \\
\text { hoss } \\
(\mu \mathrm{m})\end{array}$} & \multirow[b]{2}{*}{$\begin{array}{l}\text { Prizmahossz } \\
\qquad(\mu \mathrm{m})\end{array}$} & \multirow[b]{2}{*}{$\begin{array}{l}\text { Vastagkig } \\
(\mu \mathrm{m})\end{array}$} & \multirow[b]{2}{*}{$\begin{array}{l}{ }^{` H e} \\
(\mathrm{ncc})\end{array}$} & \multirow[b]{2}{*}{$\begin{array}{l}\text { Isd } \\
\text { (\%) } \\
\end{array}$} & \multirow[b]{2}{*}{$\begin{array}{l}{ }^{10} \mathrm{Th} \\
\text { (ng) } \\
\end{array}$} & \multirow[b]{2}{*}{$\begin{array}{l}\text { Isd } \\
(\%)\end{array}$} & \multirow[b]{2}{*}{$\begin{array}{l}{ }^{20} \mathrm{U} \\
(\mathrm{ng})\end{array}$} & \multirow[b]{2}{*}{$\begin{array}{l}\text { Isd } \\
(\%) \\
\end{array}$} & \multirow[b]{2}{*}{$\begin{array}{l}\text { TAU } \\
(\%) \\
\end{array}$} & \multirow[b]{2}{*}{$\mathrm{Th} / \mathrm{U}$} & \multirow[b]{2}{*}{$\mathrm{F}_{\mathrm{I}}$} & \multirow[b]{2}{*}{$F_{\text {, hiba }(\%)}$} & \multicolumn{2}{|l|}{ Korrigálatlan } & \multicolumn{2}{|c|}{$F_{\text {-korrigalt }}$} & \multicolumn{3}{|c|}{ U-Pb korrigalt } & \multicolumn{2}{|c|}{$\begin{array}{l}\text { Teljes nem- } \\
\text { egyensúlyra } \\
\text { korrigalt }\end{array}$} \\
\hline & & & & & & & & & & & & & & $\begin{array}{c}(\mathrm{U}-\mathrm{Th}) / \mathrm{He} \\
\text { kor (ka) }\end{array}$ & $\begin{array}{r}\text { Isd } \\
(\mathrm{ka})\end{array}$ & $\begin{array}{c}(\mathrm{U}- \\
\mathrm{Th}) / \mathrm{He} \\
\mathrm{kor} \\
(\mathrm{ka})\end{array}$ & $\begin{array}{l}\text { Isd } \\
\text { (ka) }\end{array}$ & D230 & $\begin{array}{c}(\mathrm{U}- \\
\text { Th)/He } \\
\text { kor } \\
\text { (ka) }\end{array}$ & $\begin{array}{l}1 \mathrm{sd} \\
(\mathrm{ka})\end{array}$ & $\begin{array}{c}(\mathrm{U}- \\
\text { Th)/He } \\
\text { kor } \\
(\mathrm{ka}) \\
\end{array}$ & $\begin{array}{c}\text { Isd } \\
(\mathrm{ka} \\
1\end{array}$ \\
\hline NH5 zl & 222 & 118 & 76 & 0,332 & 1,7 & 3,2 & 2,4 & 3,5 & 1,8 & 2,3 & 0,92 & 0,741 & 7,8 & 651 & 15 & 879 & 71 & 0,29 & 888 & 86 & 926 & 75 \\
\hline NH5 22 & 251 & 136 & 95 & 0,387 & 1,7 & 2,6 & 2,4 & 4,3 & 1,8 & 2,3 & 0,60 & 0,801 & 6,0 & 658 & 15 & 821 & 53 & 0,19 & 828 & 57 & 878 & 56 \\
\hline NH5 z3 & 258 & 130 & 77 & 0,261 & 1,9 & 2,0 & 2,4 & 3,1 & 1,8 & 2,5 & 0,64 & 0,748 & 7,6 & 610 & 15 & 816 & 65 & 0,20 & 821 & 70 & 873 & 69 \\
\hline NH5 $z 4$ & 277 & 186 & 90 & 0,782 & 1,6 & 13,0 & 2,4 & 7,1 & 1,8 & 2,2 & 1,83 & 0,783 & 6,5 & 639 & 14 & 816 & 56 & 0,57 & 815 & 58 & 841 & 58 \\
\hline NH5 z 5 & 271 & 143 & 123 & 0,678 & 1,6 & 3,8 & 2,4 & 6,9 & 1,8 & 2,2 & 0,55 & 0,830 & 5,1 & 725 & 16 & 874 & 49 & 0,17 & 893 & 63 & 933 & 52 \\
\hline NH5 z6 & 219 & 137 & 86 & 0,250 & 1,8 & 1,7 & 2,4 & 2,8 & 1,8 & 2,4 & 0,61 & 0,771 & 6,9 & 640 & 15 & 830 & 60 & 0,19 & 837 & 67 & 887 & 65 \\
\hline & & & & & & & & & & & & & $\begin{array}{c}\text { súlyozott } \\
\text { átlagok (ka): }\end{array}$ & 652 & 17 & 839 & 23 & & 843 & 27 & 890 & 25 \\
\hline & & & & & & & & & & & & & & & & & 800 & of fit: & 0,922 & & & \\
\hline
\end{tabular}




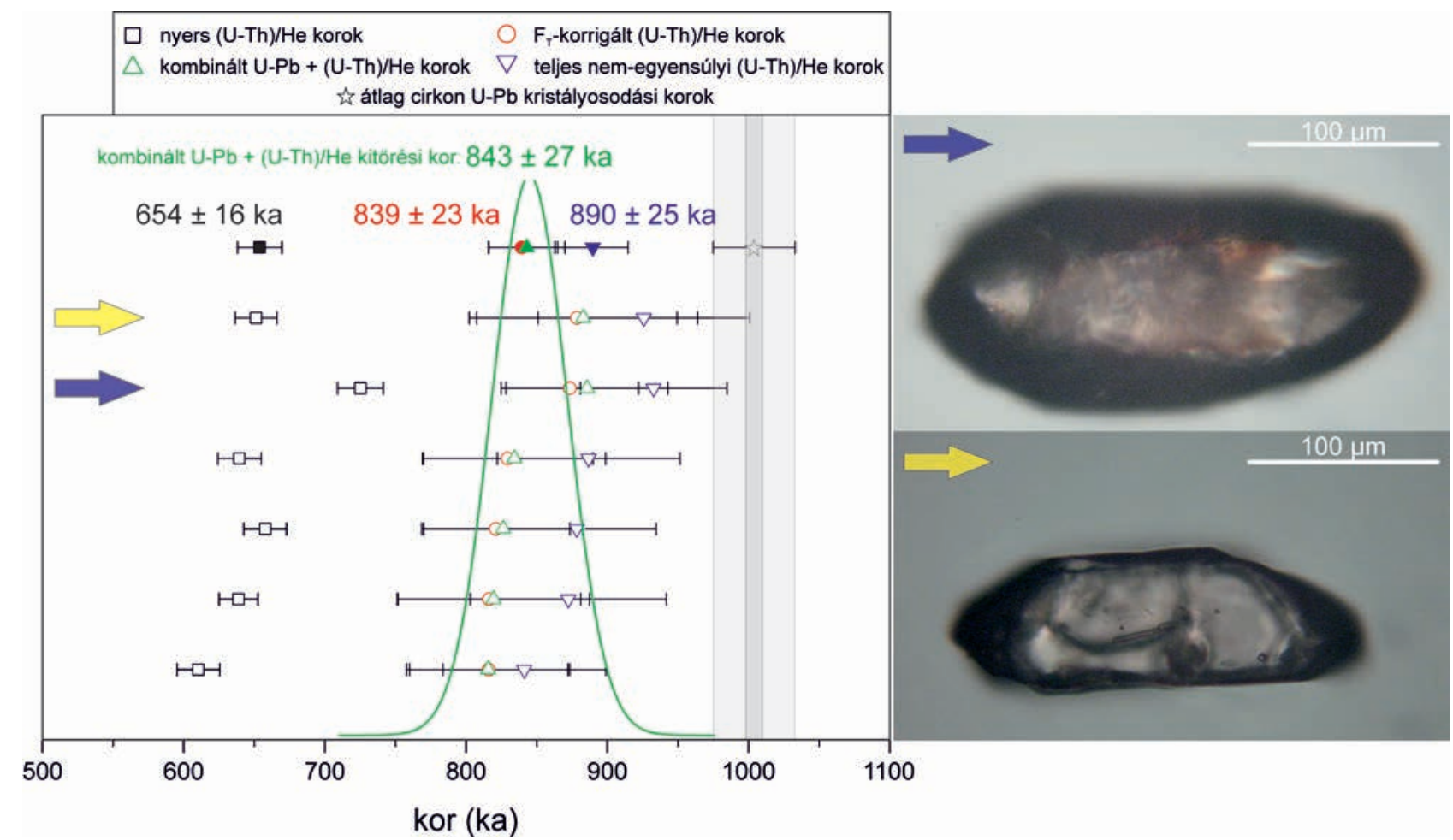

10. ábra. (U-Th)/He koreredmények a nagy-hegyesi minta cirkonjaiból: a nyers, $\mathrm{F}_{\mathrm{T}}$-korrigált, kombinált U-Pb és (U-Th)/He (kitörési kor), valamint teljes nem egyensúlyi egyedi He-korok, a hozzájuk tartozó bizonytalanságokkal együtt, az egyes jelölések színével megegyező feliratok az ezekből számolt súlyozott átlagokat és ezek bizonytalanságait mutatja. Ezen kívül az ábrán feltüntettük az átlagos U-Pb kristályosodási korokat, és a hozzájuk tartozó bizonytalanságot (LuKÁcs R., szóbeli közlés) is. A kék és sárga nyíllal jelölt cirkonkristály a mintából származó legnagyobb (kék nyíl) és legkisebb (sárga nyíl) $\mathrm{F}_{\mathrm{T}}$-értékkel rendelkező kristály fotója, a hozzájuk tartozó koreredményeket a baloldali ábrán a megegyező színủ nyilak jelölik

Figure 10. The individual raw-, $F_{T}$-corrected, combined U-Pb and (U-Th)/He (i.e. eruption age) and full disequilibrium (U-Th)/He ages of the sample NH with their uncertainties. The corresponding titles are the calculated weighted means of the raw, $F_{T}$-corrected, combined U-Pb and (U-Th)/He and full disequilibrium ages and their uncertainties. The average U-Pb crystallization age with its uncertainties is also indicated. The blue and yellow arrows indicate the biggest and the smallest crystals of the sample, respectively. Their age results are indicated by the same color arrows

alfa kilökődési korrekció bizonytalanságát is, amelyek egyik kristály esetében sem haladják meg a 10\%-ot, így az átlagszámításnál mindegyiket figyelembe vettük. $\mathrm{Az} \mathrm{F}_{\mathrm{T}^{-}}$ korrigált korok súlyozott átlaga $839 \pm 23$ ezer évet adott eredményül (10. ábra; $\mathrm{F}_{\mathrm{T}}$-korrigált (U-Th)/He-korok).

A számolt $\mathrm{F}_{\mathrm{T}}$-értékekben, valamint az egyedi $\mathrm{F}_{\mathrm{T}}$-korrigált korok vizsgálatában megmutatkozik, hogy milyen nagy szerepe van annak, hogy milyen kristályokat választottunk ki a mérésre. Ugyanis a korrekció alapegyenleteiból következik, hogy az $\mathrm{F}_{\mathrm{T}}$ értékére legnagyobb hatással a kristály mérete van (6. egyenlet), valamint hogy minél jobban közelít ez a szám 1-hez, annál kisebb a korrekció mértéke (4. egyenlet). Ez a közölt nagy-hegyesi adatsorban úgy mutatkozik meg, hogy a legnagyobb, 'z5' számú kristályhoz tartozik a legnagyobb $\mathrm{F}_{\mathrm{T}}$-érték, és itt a legkisebb az eltérés a korrigálatlan, nyers és az $\mathrm{F}_{\mathrm{T}}$-korrigált (U-Th)/He kor között (III. táblázat: $\mathrm{NH} \mathrm{z5}$; valamint 10. ábra, kék nyíllal jelzett adat, illetve cirkonkristály). Ezzel szemben a legkisebb, z1 számú kristály rendelkezik a legkisebb $\mathrm{F}_{\mathrm{T}}$ értékkel, és a korrigálatlan és az $\mathrm{F}_{\mathrm{T}}$-korrigált kor között ennél a kristálynál

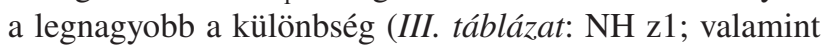
10. ábra, sárga nyíllal jelzett adat, illetve cirkonkristály).

Mint korábban említettük, a cirkon (U-Th)/He kormérés esetében, ha a vizsgált minta $\sim$ millió évnél fiatalabb, szükséges a cirkon kristályosodásakor fellépő ${ }^{230} \mathrm{Th}$ frakcionáci- ójának a hatásával és az ebből fakadó nem egyensúlyi állapottal számolni. A nagy-hegyesi lávadóm példáján keresztül bemutatjuk egyrészt a teljes nem egyensúlyi korrekciós számolás eredményeit, valamint a rendelkezésünkre álló kristályosodási korok segítségével elvégezzük az U-Pb korrekciót is, megadva a minta pontos kitörési korát. Azért is szükséges a teljes nem egyensúlyi korrekciós számolást elvégezni, mert így kijelölhetô a minta maximális kora, amely segítséget nyújt az adatértéklésben (az esetleges idős korok kiszúrésében), valamint szemléletessé teszi a cirkon magmakamrabeli tartózkodási idejének hatását is a kapott korra adott minta esetében.

A rendelkezésünkre álló cirkon U-Pb kristályosodási

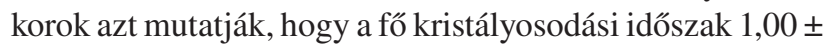
0,03 millió évvel ezelőtt zajlott, míg a mintából meghatározott legfiatalabb U-Pb kor 0,86 \0,06 millió év ( LUKÁCS R., szóbeli közlés). A korrekció során a kristályosodási korok súlyozott átlagát használtuk fel. Mind a két számolás a SCHMITT és munkatársai (2010) által közölt MCHeCalc program segítségével történt, a kapott korokat pedig, a hozzájuk tartozó bizonytalanságokkal a III. táblázat tartalmazza. Az egyedi U-Pb korrigált (U-Th)/He korok 814 ezer és 893 ezer év közé esnek (10. ábra; kombinált U-Pb + (UTh)/He korok), a teljes populációra számolt kitörési kor pedig $843(+28,-25)$ ezer év ('goodness of fit': 0,922). A 
teljes nem egyensúlyi állapotot feltételezô eredmények 841 ezer és 933 ezer év között mozognak, súlyozott átlaguk 890 \pm 25 ezer év (10. ábra; teljes nem egyensúlyi (U-Th)/He korok). A teljes nem egyenúlyi állapotot feltételező korok hibahatáron kívül esnek a szekuláris egyensúlyt feltételező(UTh)/He koroktól, amely jelzi a korrekció szükségességét. Az átlag U-Pb kristályosodási korokkal elvégzett korrekció ugyanakkor hibahatáron belül megegyezik a szekuláris egyensúlyt feltételező (U-Th)/He korral, amely azt mutatja, hogy idősebb (0,5-1 M év) minták esetében megfelelôen nagy (>100 ezer év) tartózkodási idó esetén a szekuláris egyensúlyt feltételező (U-Th)/He kor jól közelíti a kitörési kort.

Az értelmezett kitörési kor fiatalabb, mint korábban a Nagy-Hegyes felépülésére publikált teljes-kőzet K-Ar kor (1,02 $\pm 0,07$ M év; SzAKÁcs et al. 2015). Ennek az eltérésnek az lehet az oka, hogy a fiatal ( $<2$ millió év) minták esetében, különösen akkor, ha a mérés nem üde, egyedi ásványfázisokon (pl. leucit vagy szanidin), hanem ezek hiányában teljeskőzet-mintán történik (vagy akár biotiton, amfibolon), akkor az Ar-többlet hatása a ténylegesnél idősebb kort eredményezhet (pl. HorA et al. 2007, HILDENBRAND et al. 2012).

Mindezek alapján elmondható, hogy a nagy-hegyesi lávadóm felépülése $843 \pm 27$ ezer évvel ezelótt következett be.

\section{A bükszádi piroklasztár-üledék}

A Csomád központi ikerkráterétől délre, Sepsibükszád (Bixad) településtôl $~ 3 \mathrm{~km}$-re keletre található feltárás felfedezése VINKLER és munkatársai (2007) nevéhez kötődik. A piroklasztár-üledék leírását, valamint az ezt létrehozó kitörés korát az említett tanulmányon kívül több szerző is közli (HARANGI et al. 2010, 2015a; KARÁTSON et al. 2016). Először radiokarbon kormeghatározás történt az üledékben található szenesedett növénymaradványokon (VINKLER et al. 2007, HARANGI et al. 2010), amelyek alapján a kitörési kor 31,230-32,700 cal BP évre tehetô. HARANGI és munkatársai (2015a) a piroklasztár-üledékből egyedi horzsaköveket gyúitöttek kombinált cirkon (U-Th) és (U-Th)/He kormeghatározás céljából. A mérési adatok értékelése alapján a kitörési korra 32,6 $(+1,0 ;-1,0)$ ezer évet határoztak meg, ami hibahatáron belül jó egyezést mutat a radiokarbon koreredményekkel.
A piroklasztár-üledékből gyújtött horzsakövekből a minta-elókészítés, valamint a mikroszkópos vizsgálatok után 5 cirkonkristályt választottunk ki az (U-Th)/He kormeghatározásra, amelyek a rendelkezésre álló nehézásványfrakcióból a leginkább megfeleltek az Analitikai eljárásban ismertetett feltételeknek (vagyis lehetóleg ép, sajátalakú, törés- és zárványmentes). A kiválogatott kristályok méreteit, a kapott mérési adatokat, az ezekbôl számolt egyedi korokat, valamint ezek súlyozott átlagait és a hozzájuk tartozó bizonytalanságot a $I V$. táblázat, valamint a 11 . ábra tartalmazza.

A nyers (korrigálatlan) korok 20 és 31 ezer év közé esnek (11. ábra; nyers (U-Th)/He-korok), ezek az értékek azonban még nem tartalmazzák az $\alpha$-kilökődésből származó Hehiányt, ezért szükséges az alaki $\left(\mathrm{F}_{\mathrm{T}}\right)$ korrekciós számolás az egyedi korokon. A nyers (U-Th)/He-korokhoz tartozó bizonytalanságok (IV. táblázat; TAU) itt kicsit nagyobbak (max. 5\%), mint a nagy-hegyesi minta esetében. Ez egyszerúen a minta fiatalságából fakad, a kristályokban jelen lévő He mennyisége közelebb esik a tömegspektrométer kimutatási határához, megnövelve az analitikai hibát. Az egyedi nyers (U-Th)/He korokból számolt $\mathrm{F}_{\mathrm{T}}$-korrigált korok 25 ezer és 37 ezer év közé esnek (11. ábra; $\mathrm{F}_{\mathrm{T}}$-korrigált [U$\mathrm{Th}] /$ He-korok). Az ezekhez a koradatokhoz tartozó bizonytalanság már tartalmazza az alfa kilökődési korrekció bizonytalanságát is, amelyek egyik kristály esetében sem haladják meg a 10\%-ot, így az átlagszámításnál, valamint a további számolásoknál mindegyik adatot figyelembe vettük. Az $\mathrm{F}_{\mathrm{T}}$-korrigált korok súlyozott átlaga $29 \pm 2$ ezer évet adott eredményül (11. ábra; $\mathrm{F}_{\mathrm{T}}$-korrigált (U-Th)/He-korok).

A minta fiatal korából adódóan itt is elengedhetetlen a ${ }^{230} \mathrm{Th}$ frakcionáció okozta nem egyensúlyi hatás mértékének meghatározása és korrigálása. A mérések során kapott legfiatalabb U-Th kristályosodási kor 63,1 $(+5,1,-4,9)$ ezer év, a kristályok felszínén történt mérések súlyozott átlaga 125 $(+14,-14)$ ezer év, míg a kristályok köpenyzónáiból származó U-Th kristályosodási korok súlyozott átlaga 195 (+15, -14) ezer év (11. ábra), amely a későbbi számolások során bemenő adatként is szolgált. A nem egyenúlyi állapotot figyelembe vevő kitörési kor számolása ennél a mintánál is a $\mathrm{MCHeCalc} \mathrm{program} \mathrm{segítségével} \mathrm{történt} \mathrm{(SchMiTT} \mathrm{et} \mathrm{al.}$ 2010). Az így kapott egyedi U-Th korrigált (U-Th)/He korok

IV. táblázat. A bükdszádi piroklasztár-üledék horzsaköveiből származó cirkon (U-Th)/He eredmények (HARANGI et al. 2105a alapján)

Table IV. The zircon (U-Th)/He results of the pyroclastic sample Bx (after HARANGI et al., 2105a)

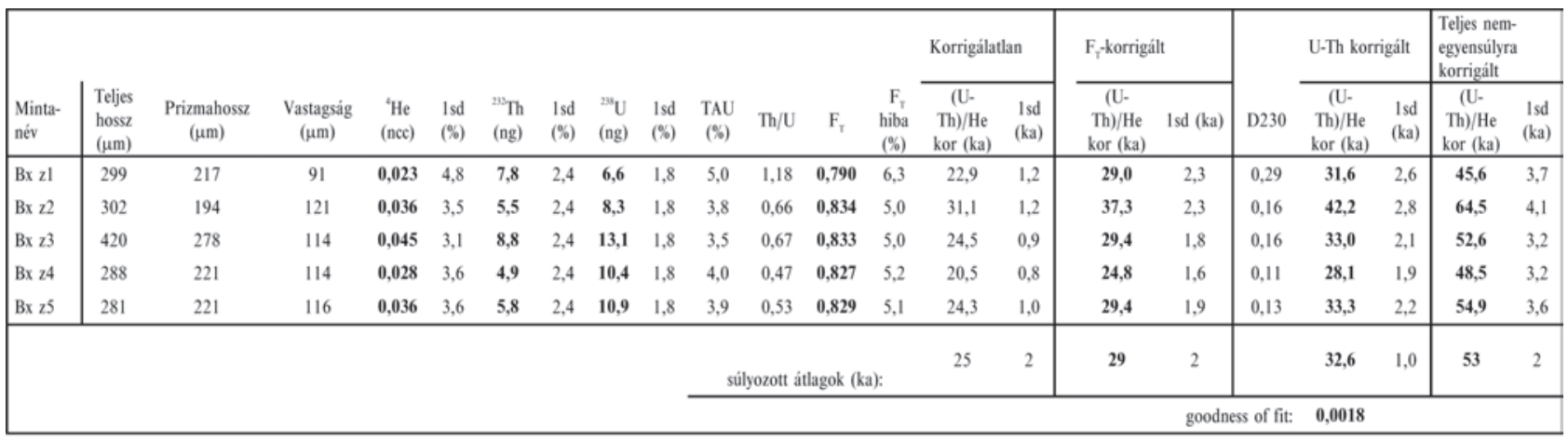




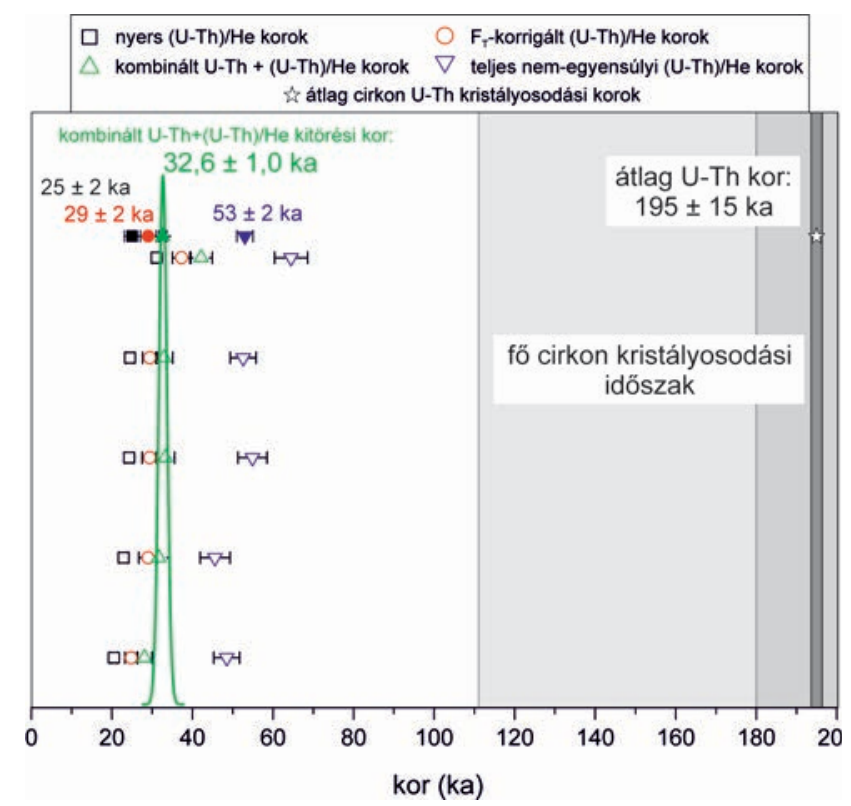

11. ábra. (U-Th)/He koreredmények a bükdszádi minta cirkonjaiból: a nyers, $\mathrm{F}_{\mathrm{T}}$-korrigált, kombinált U-Th és (U-Th)/He (kitörési kor), valamint teljes nem egyensúlyi egyedi He korok, a hozzájuk tartozó bizonytalanságokkal együtt, az egyes jelölések színével megegyező feliratok az ezekből számolt súlyozott átlagokat és ezek bizonytalanságait mutatja. Ezen kívül az ábrán feltüntettük az átlagos U-Th kristályosodási korokat, és a hozzájuk tartozó bizonytalanságot (adatok forrása: HARANGI et al. 2015a alapján)

Figure 11. The individual raw-, $F_{T}$-corrected, U-Th corrected and full disequilibrium corrected $(U-T h) / H e$ ages of the sample Bx with their uncertainties. The corresponding titles are the calculated weighted means of the raw, $F_{T}$-corrected, combined U-Th and (U-Th)/He and full disequilibrium ages and their uncertainties. The average U-Th crystallization age with its uncertainties is also indicated (after HARANGI et al. 2015a)

28 és 42 ezer év közé esnek (IV. táblázat), a teljes populációra számolt kitörési kor 32,6 (+1,0,-1,0) ezer év (11. ábra; kombinált U-Th + (U-Th)/He korok), az illesztés jóságának az értéke ('goodness of fit') pedig 0,0018.

Ennek a lelőhelynek a példája is jól tükrözi, hogy milyen hatással van a cirkon magmakamrában eltöltött tartózkodási ideje a szekuláris egyensúlyra. Ugyanis, ha megnézzük itt is azt az elméleti esetet, hogy a kristályosodási korokat figyelmen kívül hagyva mi lenne a minta kora akkor, ha 0 tartózkodási idővel számolunk, $53 \pm 2$ ezer évet kapunk eredményül a teljes nem egyensúlyi (U-Th)/He korra (11. ábra; teljes nem egyensúlyi (U-Th)/He korok). Az adatok értékelésében, a kiugró adatok kiszúrésében ez az adat segítséget nyújt, megadva azt a maximális kort (e minta esetében $53 \pm 2$ ezer év), aminél korábban nem történhetett a kitörés. Tehát ha az adatsorban ennél idősebb korok szerepelnek, azok jó eséllyel korábbi felkapott kristályok. A bükszádi minta esetében azonban nem szerepel olyan, egyedi kristályból származó He-kor, amely meghaladná a teljes nem egyensúlyi (U-Th)/He-kort, még jobban alátámasztva, hogy a kitörési kor számolásánál az össszes mért adat figyelembe vétele szükséges.

Mindezek alapján elmondható tehát, hogy a bükszádi piroklasztár-üledéket létrehozó kitörés a kombinált cirkon U-Th és (U-Th)/He mérések alapján, jó összhangban a radiokarbon koreredményekkel 32 ezer évvel ezelőtt következett be.

\section{Összefoglalás}

Munkánkkal először összegeztük magyar nyelven az (UTh)/He geokronológia legfontosabb elméleti és gyakorlati alapjait, valamint a továbbfejlesztési lehetôségeit (in situ mérések, zónásság okozta problémák) is. Ez az összefoglaló anyag jól tükrözi, hogy a módszer ismerete, használata megkerülhetetlen különféle alacsony hőmérsékletú termokronológiai kutatásokban, valamint fiatal vulkánkitörések korának meghatározásában is.

Az (U-Th)/He geokronológia alkalmazhatóságát fiatal kitörések (<1 millió év) kormeghatározására a bemutatott esettanulmányok is alátámasztják. Ezek a példák a KárpátPannon térség legfiatalabb vulkáni múködéseihez kapcsolódó kitörési termékek, a két lelőhely a Nagy-Hegyes andezites lávadómja, valamint bükszádi piroklasztár-üledék. A vulkáni múködés korának meghatározása számos cirkon egyedi elemzésén alapul. A He-izotóp, valamint U és Th mérések eredményeiből, a cirkonkristály alaki sajátságait figyelembe véve számoljuk ki az adott kristály He korát. Az 1 millió évnél fiatalabb minták esetében fontos a nem egyensúlyi izotóp állapotból adódó korrekció, amihez nélkülözhetetlen a kristályosodási idő ismerete. Ehhez U-Th vagy U-Pb izotópos kormeghatározás szükséges. Bár ismerjük, hogy a kapott koradatok értéke függ a kristály belső U-koncentráció változásától, ennek pontos számszerúsített hatását nem tudjuk még megadni. Ez a hatás azonban beépíthető a megadott koradat bizonytalanságába. A kitörési idő a mért egyedi cirkonkristályok korértékeinek statisztikai kiértékelésén alapul. E szigorú értelmezési keretben kapott (U-Th)/He kitörési korok fontos szerepet kaphatnak a fiatal vulkáni kitörések idejének pontosabb megismerésében, vulkánok aktív és szunnyadási időszakainak meghatározásában.

\section{Köszönetnyilvánítás}

A szerzők köszönettel tartoznak DunKLNÉ NAGY Juditnak (Göttingen) a mérések során, Axel K. ScHMITTnek (Heidelberg) az adatok értékelésében, GARAMHEGYI Tamásnak a térkép elkészítésben, valamint az MTA-ELTE Vulkanológiai Kutatócsoport tagjainak a mintagyújtésben nyújtott segítségükért. Köszönjük továbbá bírálóinknak, BENKó Zsoltnak és Kiss Balázsnak a javításokat és segítő tanácsaikat, valamint SzTANó Orsolyának és PIROS Olgának a szerkesztői munkájukat. A göttingeni mérések egy része az ELTE Tehetséggondozási Tanács támogatatása révén valósult meg. LuKÁcs Réka munkája a PD 121048 számú projekthez kapcsolódik, ami a Nemzeti Kutatási, Fejlesztési és Innovációs Hivatal támogatásával az NFKI alapból valósult meg. Jelen munka az K116528 sz. OTKA pályázat része. 


\section{Irodalom — References}

Aciego, S., Kennedy, B. M., Depaolo, D. J., Christensen, J. N. \& Hutcheon, I. 2003: U-Th/He age of phenocrystic garnet from the 79 AD eruption of Mt. Vesuvius. — Earth and Planetary Science Letters 216/1-2, 209-219. http://doi.org/10.1016/S0012-821X(03)00478-3

ARATó R. 2014: A Recski magmás komplexum geo- és termokronológiája. —Ásványtani Tanszék MSc, 106 p.

Ault, A. K., Reiners, P. W., Evans, J. P. \& Thomson, S. N. 2015: Linking hematite (U-Th)/He dating with the microtextural record of seismicity in the Wasatch fault damage zone, Utah, USA. — Geology 43/9, 771-774. http://doi.org/10.1130/G36897.1BARGNESI, E. A., Stockli, D. F., Hourigan, J. K. \& Hager, C. 2016: Improved accuracy of zircon (U-Th)/He ages by rectifying parent nuclide zonation with practical methods. — Chemical Geology 426, 158-169. http://doi.org/10.1016/j.chemgeo.2016.01.017

Bateman, H. 1910: Solution of a System of Differential Equations Occurring in the Theory of Radio-active Transformations. — Proc. Cambridge Philos. Soc. 15, 423-427.

Bourdon, B., Zindler, A. \& Wörner, G. 1994: Evolution of the Laacher See magma chamber: Evidence from SIMS and TIMS measurements of U-Th disequilibria in minerals and glasses. — Earth and Planetary Science Letters 126/1-3, 75-90. http://doi.org/ $0.1016 / 0012-821 X(94) 90243-7$

Braun, J., VAn DeR BeEK, P. \& BatT, G. 2012: Quantitative Thermochronology: Numerical Methods for the Interpretation of Thermochronological Data. — Cambridge University Press, 272 p. http://doi.org/10.2277/0521830575

Charlier, B. \& ZellmER, G. 2000: Some remarks on U-Th mineral ages from igneous rocks with prolonged crystallisation histories. Earth and Planetary Science Letters 183/3-4, 457-469. http://doi.org/10.1016/S0012-821X(00)00298-3

Cheng, H., Edwards, R. L., Hoff, J., Gallup, C. D., Richards, D. A. \& Asmerom, Y. 2000: The half-lives of uranium-234 and thorium230. - Chemical Geology 169/1-2, 17-33. http://doi.org/10.1016/S0009-2541(99)00157-6

Cloetingh, S. A. P. L., Burov, E., Matenco, L., Toussaint, G., Bertotti, G., Andriessen, P. A. M., Wortel, M. J. R. \& Spakman, W. 2004: Thermo-mechanical controls on the mode of continental collision in the SE Carpathians (Romania). — Earth and Planetary Science Letters 218/1-2, 57-76. http://doi.org/10.1016/S0012-821X(03)00645-9

Csontos, L., Nagymarosy, A., Horváth, F. \& Kovác, M. 1992: Tertiary evolution of the Intra-Carpathian area: A model. — Tectonophysics 208/1-3, 221-241. http://doi.org/10.1016/0040-1951(92)90346-8

Daniší́, M., Shane, P., Schmitt, A. K., HogG, A., Santos, G. M., Storm, S., Evans, N. J., Keith Fifield, L. \& Lindsay, J. M. 2012 : Reanchoring the late Pleistocene tephrochronology of New Zealand based on concordant radiocarbon ages and combined ${ }^{238} \mathrm{U} /{ }^{230} \mathrm{Th}$ disequilibrium and (U-Th)/He zircon ages. — Earth and Planetary Science Letters 349-350, 240-250. http://doi.org/10.1016/ j.eps1.2012.06.041

Danišík, M., Fodor, L., DunkL, I., Gerdes, A., Csizmeg, J., Hámor-Vidó, M. \& Evans, N. J. 2015: A multi-system geochronology in the Ad-3 borehole, Pannonian Basin (Hungary) with implications for dating volcanic rocks by low-temperature thermochronology and for interpretation of (U-Th)/He data. - Terra Nova 27/4, 258-269. http://doi.org/10.1111/ter.12155

Danišík, M., Schmitt, A. K., Stockli, D. F., Lovera, O. M., DunkL, I. \& Evans, N. J. 2016: Application of combined U-Th-disequilibrium/U-Pb and (U-Th)/He zircon dating to tephrochronology. — Quaternary Geochronology 40, 23-32. http://doi.org/10.1016/ j.quageo.2016.07.005

Dodson, M. H. 1973: Closure temperature in cooling geochronological and petrological systems. — Contributions to Mineralogy and Petrology 40/3, 259-274. http://doi.org/10.1007/BF00373790

Dosseto, A., Turner, S. P. \& VAn Orman, J. A. 2010: Magma Cooling and Differentiation — Uranium-Series Isotopes. — Dosseto, A. \& TuRner, S. P. (eds): Timescales of Magmatic Processes. 160-180. http://doi.org/10.1002/9781444328509.ch8

Evans, N. J., Wilson, N. S. F., Cline, J. S., Mcinnes, B. I. A. \& BYrne, J. 2005: Fluorite (U-Th)/He thermochronology: Constraints on the low temperature history of Yucca Mountain, Nevada. — Applied Geochemistry 20/6, 1099-1105. http://doi.org/10.1016/ j.apgeochem.2005.02.008

Evans, N. J., Mcinnes, B. I. A., Mcdonald, B., Danišik, M., Becker, T., Vermeesch, P., Shelley, M., Marillo-Sialer, E. \& Patterson, D. B. 2015: An in situ technique for (U-Th-Sm)/He and U-Pb double dating. - Journal of Analytical Atomic Spectrometry 30/7, 1636-1645. http://doi.org/10.1039/C5JA00085H

Evenson, N. S., Reiners, P. W., Spencer, J. E. \& Shuster, D. L. 2014: Hematite and Mn oxide (U-Th)/He dates from the BuckskinRawhide detachment system, western Arizona: Gaining insights into hematite (U-Th)/He systematics. — American Journal of Science 314/10, 1373-1435. http://doi.org/10.2475/10.2014.01

FAbBrizio, A., SCHMidT, M. W., GÜNTHER, D. \& EIKENBERG, J. 2008: Experimental determination of radium partitioning between leucite and phonolite melt and ${ }^{226}$ Ra-disequilibrium crystallization ages of leucite. - Chemical Geology 255/3-4, 377-387. http://doi.org/ 10.1016/j.chemgeo.2008.07.008

FARLEY, K. A. 2002: (U-Th)/He Dating: Techniques, Calibrations, and Applications. — Reviews in Mineralogy and Geochemistry 47/1, 819-844. http://doi.org/10.2138/rmg.2002.47.18

Farley, K. A., Wolf, R. A. \& Silver, L. T. 1996: The effects of long alpha-stopping distances on (U-Th)/He ages. — Geochimica et Cosmochimica Acta 60/21, 4223-4229. http://doi.org/10.1016/S0016-7037(96)00193-7

FARLEY, K. A., KoHn, B. P. \& Pillans, B. 2002: The effects of secular disequilibrium on (U-Th)/He systematics and dating of Quaternary volcanic zircon and apatite. — Earth and Planetary Science Letters 201/1, 117-125. http://doi.org/10.1016/S0012-821X(02)00659-3

Fechtig, H. \& Kalbitzer, S. 1966: The Diffusion of Argon in Potassium-Bearing Solids. — (eds): Potassium Argon Dating. Berlin, Heidelberg, 68-107. http://doi.org/10.1007/978-3-642-87895-4_4

FitzGerald, P. G., Baldwin, S. L., WebB, L. E. \& O'sullivan, P. B. 2006: Interpretation of (U-Th)/He single grain ages from slowly cooled crustal terranes: A case study from the Transantarctic Mountains of southern Victoria Land. - Chemical Geology 225/1-2, 91-120. http://doi.org/10.1016/j.chemgeo.2005.09.001 
Gebauer, S. K., Schmitt, A. K., Pappalardo, L., Stockli, D. F. \& LoverA, O. M. 2014: Crystallization and eruption ages of Breccia Museo (Campi Flegrei caldera, Italy) plutonic clasts and their relation to the Campanian ignimbrite. - Contributions to Mineralogy and Petrology 167/1, p. 953. http://doi.org/10.1007/s00410-013-0953-7

Guenthner, W. R., Reiners, P. W., Ketcham, R. A., Nasdala, L. \& Giester, G. 2013: Helium diffusion in natural zircon: Radiation damage, anisotropy, and the interpretation of zircon (U-Th)/He thermochronology. — American Journal of Science 313/3, 145-198. http://doi.org/10.2475/03.2013.01

Hager, C. \& Stockli, D. F. 2009: A new Matlab@-based Helium Modeling Package ("HeMP") for thermal history recovery from single and multi-thermochronometer (U-Th)/He data and data arrays. — Geol. Soc. Am. Abstr. Programs $41,487$.

Haider, V. L., Dunkl, I., Eynatten, H. V., Ding, L., Frei, D. \& Zhang, L. 2013: Cretaceous to Cenozoic evolution of the northern Lhasa Terrane and the Early Paleogene development of peneplains at Nam Co, Tibetan Plateau. _ Journal of Asian Earth Sciences 70-71, 79-98. http://doi.org/10.1016/j.jseaes.2013.03.005

Hames, W. E. \& Bowring, S. A. 1994: An empirical evaluation of the argon diffusion geometry in muscovite. - Earth and Planetary Science Letters 124/1, 161-169. http://doi.org/10.1016/0012-821X(94)00079-4

Harangi, S. 2001: Neogene to Quaternary volcanism of the Carpathian-Pannonian Region — a review. — Acta Geologica Hungarica 44, 223-258.

HARANGi, S. \& LENKEY, L. 2007: Genesis of the Neogene to Quaternary volcanism in the Carpathian-Pannonian region: Role of subduction, extension, and mantle plume. _ Geological Society of America Special Papers 418, 67-92. http://doi.org/ 10.1130/2007.2418(04)

Harangi, S., Molnár, M., Vinkler, A. P., Kiss, B., Jull, A. J. T. \& Leonard, A. G. 2010: Radiocarbon dating of the last volcanic eruptions of Ciomadul volcano, Southeast Carpathians, Eastern-Central Europe. — Radiocarbon 52/2-3, 1498-1507.

Harangi, S., SÁGi, T., Seghedi, I. \& Ntaflos, T. 2013: Origin of basaltic magmas of Perşani volcanic field, Romania: A combined whole rock and mineral scale investigation. — Lithos 180-181, 43-57. http:// doi.org/10.1016/j.lithos.2013.08.025

Harangi, S., Lukács, R., Schmitt, A. K., Dunkl, I., Molnár, K., Kiss, B., Seghedi, I., Novothny, Á. \& Molnár, M. 2015a: Constraints on the timing of Quaternary volcanism and duration of magma residence at Ciomadul volcano, east-central Europe, from combined U-Th/He and U-Th zircon geochronology. — Journal of Volcanology and Geothermal Research 301, 66-80. http://doi.org/ 10.1016/j.jvolgeores.2015.05.002

Harangi, S., Novák, A., Kiss, B., Seghedi, I., LukÁcs, R., Szarka, L., WeszTergom, V., Metwaly, M. \& GribovszKi, K. 2015b: Combined magnetotelluric and petrologic constrains for the nature of the magma storage system beneath the Late Pleistocene Ciomadul volcano (SE Carpathians). _ Journal of Volcanology and Geothermal Research 290, 82-96. http://doi.org/10.1016/ j.jvolgeores.2014.12.006

Harrison, T. M. 1982: Diffusion of ${ }^{40} \mathrm{Ar}$ in hornblende. - Contributions to Mineralogy and Petrology 78/3, 324-331. http://doi.org/ 10.1007/BF00398927

Harrison, T. M., Duncan, I. \& McDougall, I. 1985: Diffusion of ${ }^{40}$ Ar in biotite: Temperature, pressure and compositional effects. Geochimica et Cosmochimica Acta 49/11, 2461-2468. http://doi.org/10.1016/0016-7037(85)90246-7

HARrison, T. M., WATSON, E. B. \& AIKMAN, A. B. 2007: Temperature spectra of zircon crystallization in plutonic rocks. — Geology 35/7, 635-638. http://doi.org/10.1130/G23505A.1

Hiess, J., Condon, D. J., Mclean, N. \& Noble, S. R. 2012: ${ }^{238}$ U/235U Systematics in Terrestrial Uranium-Bearing Minerals. — Science 335/6076, 1610-1614. http://doi.org/10.1126/science.1215507

Hildenbrand, A., Marques, F. O., Costa, A. C. G., Sibrant, A. L. R., Silva, P.F., Henry, B., Miranda, J. M. \& Madureira, P. 2012: Reconstructing the architectural evolution of volcanic islands from combined K/Ar, morphologic, tectonic, and magnetic data: The Faial Island example (Azores). — Journal of Volcanology and Geothermal Research 241-242, 39-48. http://doi.org/10.1016/ j.jvolgeores.2012.06.019

Hora, J. M., Singer, B. S. \& Wörner, G. 2007: Volcano evolution and eruptive flux on the thick crust of the Andean Central Volcanic Zone: ${ }^{40} \mathrm{Ar} /{ }^{39} \mathrm{Ar}$ constraints from Volcán Parinacota, Chile. — Geological Society of America Bulletin 119/3-4, 343-362. http:// dx.doi.org/10.1130/B25954.1

Horváth, F. 1993: Towards a mechanical model for the formation of the Pannonian Basin. — Tectonophysics 226/1-4, 333-357. http://doi.org/10.1016/0040-1951(93)90126-5

Horváth, F., Bada, G., Szafián, P., Tari, G., ÁdÁM, A. \& Cloetingh, S. 2006: Formation and deformation of the Pannonian Basin: constraints from observational data. — Geological Society, London, Memoirs 32/1, 191-206. http://doi.org/10.1144/GSL.MEM. 2006.032.01.11

Hourigan, J. K., Reiners, P. W. \& Brandon, M. T. 2005: U-Th zonation-dependent alpha-ejection in (U-Th)/He chronometry. — Geochimica et Cosmochimica Acta 69/13, 3349-3365. http://doi.org/10.1016/j.gca.2005.01.024

House, M. A., FArley, K. A. \& Kohn, B. P. 1999: An empirical test of helium diffusion in apatite: borehole data from the Otway basin, Australia. - Earth and Planetary Science Letters 170/4, 463-474. http://doi.org/10.1016/S0012-821X(99)00120-X

House, M. A., Wernicke, B. P., Farley, K. A. \& Dumitru, T. A. 1997: Cenozoic thermal evolution of the central Sierra Nevada, California, from (U-Th)/He thermochronometry. — Earth and Planetary Science Letters 151/3, 167-179. https://doi.org/10.1016/ S0012-821X(97)81846-8

Juvigne, E., Gewelt, M., Gilot, E., Hurtgen, C., Seghedi, I., Szakács, A., Gábris, Gy., Hadnagy, Á., Horváth, E. 1994: Une eruption vieille d'environ 10700 ans $\left({ }^{14} \mathrm{C}\right)$ dans les Carpates orientales (Roumanie). - Comptes rendus de l'Académie des sciences. Série 2. Sciences de la terre et des plančtes 318/9, 1233-1238

Karátson, D., Telbisz, T., Harangi, S., Magyari, E., Dunkl, I., Kiss, B., Jánosi, C., Veres, D., Braun, M., Fodor, E., Biró, T., Kósik, S., Von Eynatten, H. \& LIN, D. 2013: Morphometrical and geochronological constraints on the youngest eruptive activity in EastCentral Europe at the Ciomadul (Csomád) lava dome complex, East Carpathians. — Journal of Volcanology and Geothermal Research 255, 43-56. http://doi.org/10.1016/j.jvolgeores.2013.01.013 
Karátson, D., Wulf, S., Veres, D., Magyari, E. K., Gertisser, R., Timár, G., Novothny, Á., Telbisz, T., Szalai, Z., AnechiteiDeacu, V., Appelt, O., Bormann, M., Jánosi, C., Hubay, K. \& Schäbitz, F. 2016: The latest explosive eruptions of Ciomadul (Csomád) volcano, East Carpathians - A tephrostratigraphic approach for the 51-29 ka BP time interval. — Journal of Volcanology and Geothermal Research 319, 29-51. http://doi.org/10.1016/j.jvolgeores.2016.03.005

Kiss, B., Harangi, S., Ntaflos, T., Mason, P. R. D. \& PÁl-Molnár, E. 2014: Amphibole perspective to unravel pre-eruptive processes and conditions in volcanic plumbing systems beneath intermediate arc volcanoes: a case study from Ciomadul volcano (SE Carpathians). - Contributions to Mineralogy and Petrology 167/3, 1-27. http://doi.org/10.1007/s00410-014-0986-6

Klemetti, E. W. \& Clynne, M. A. 2014: Localized Rejuvenation of a Crystal Mush Recorded in Zircon Temporal and Compositional Variation at the Lassen Volcanic Center, Northern California. — PLoS ONE 9/12, e113157. http://doi.org/10.1371/journal. pone.0113157

KoneČNÝ, V., KovÁC, M., LEXA, J. \& ŠEFARA, J. 2002: Neogene evolution of the Carpatho-Pannonian region: An interplay of subduction and back-arc diapiric uprise in the mantle. - European Geophysical Union Stephan Mueller Special Publication Series 1, $105-123$.

LeE, J. K. W., Williams, I. S. \& Ellis, D. J. 1997: Pb, U and Th diffusion in natural zircon. — Nature 390/6656, 159-162. http://doi.org/ $10.1038 / 36554$

LEVENTHAL, J. S. 1975: An evaluation of the uranium-thorium-helium method for dating young basalts. — Journal of Geophysical Research 80/14-19, 11-1914. http://doi.org/10.1029/JB080i014p01911

LeXA, J. \& KonecnÝ, V. 1974: The Carpathian Volcanic Arc: a discussion. — Acta Geologica Acad. Sci. Hung. 18, $279-294$.

LEXA, J. \& KonECNÝ, V. 1998: Geodynamic aspects of the Neogene to Quaternary volcanism. — In: RAKús, M. (ed.): Geodynamic Development of the Western Carpathians. 219-240.

Lindsay, J. M., Trumbull, R. B., Schmitt, A. K., Stockli, D. F., Shane, P. A. \& Howe, T. M. 2013: Volcanic stratigraphy and geochemistry of the Soufričre Volcanic Centre, Saint Lucia with implications for volcanic hazards. — Journal of Volcanology and Geothermal Research 258, 126-142. http://doi.org/10.1016/j.jvolgeores.2013.04.011

Lippolt, H. J. \& Weigel, E. 1988: ${ }^{4}$ He diffusion in ${ }^{40}$ Ar-retentive minerals. — Geochimica et Cosmochimica Acta 52/6, $1449-1458$. http://doi.org/10.1016/0016-7037(88)90215-3

LOVERA, O. M., Richter, F. M. \& HARRISON, T. M. 1989: The ${ }^{40} \mathrm{Ar} /{ }^{39} \mathrm{Ar}$ thermochronometry for slowly cooled samples having a distribution of diffusion domain sizes. — Journal of Geophysical Research: Solid Earth 94/B12, 17917-17935. http://doi.org/ 10.1029/JB094iB12p17917

LukÁcs, R., Harangi, S., Bachmann, O., Guillong, M., Danišík, M., Buret, Y., Von Quadt, A., Dunkl, I., Fodor, L., Sliwinski, J., Soós, I. \& SZEPESI, J. 2015: Zircon geochronology and geochemistry to constrain the youngest eruption events and magma evolution of the Mid-Miocene ignimbrite flare-up in the Pannonian Basin, eastern central Europe. - Contributions to Mineralogy and Petrology 170/5, 52. http://doi.org/10.1007/s00410-015-1206-8

Mason, P. R. D., SEghedi, I., SzAKÁCS, A. \& Downes, H. 1998: Magmatic constraints on geodynamic models of subduction int he East Carpathians, Romania. — Tectonophysics 297, 157-176. http://doi.org/10.1016/S0040-1951(98)00167-X

Mcdowell, F. W., Mcintosh, W. C. \& FARLEY, K. A. 2005: A precise ${ }^{40} \mathrm{Ar}-{ }^{39} \mathrm{Ar}$ reference age for the Durango apatite (U-Th)/He and fission-track dating standard. — Chemical Geology 214/3-4, 249-263. http://doi.org/10.1016/j.chemgeo.2004.10.002

McInnes, B. I. A., Farley, K. A., Sillitoe, R. H. \& Kohn, B. P. 1999: Application of apatite (U-Th)/He thermochronometry to the determination of the sense and amount of vertical fault displacement at the Chuquicamata porphyry copper deposit, Chile. Economic Geology 94/6,937-947. http://doi.org/10.2113/gsecongeo.94.6.937

MeEsters, A. G. C. A. \& DunAI, T. J. 2002a: Solving the production-diffusion equation for finite diffusion domains of various shapes: Part I. Implications for low-temperature (U-Th)/He thermochronology. — Chemical Geology 186/3-4, 333-344. http://doi.org/ 10.1016/S0009-2541(01)00422-3

MeEsters, A. G. C. A. \& DunAI, T. J. 2002b: Solving the production-diffusion equation for finite diffusion domains of various shapes: Part II. Application to cases with -ejection and nonhomogeneous distribution of the source. - Chemical Geology 186/3-4, 347-363. http://doi.org/10.1016/S0009-2541(01)00423-5

MolnÁr K. 2014: A Csomád vulkáni komplexum geokronológiai vizsgálata (U-Th)/He módszerrel (DK-i Kárpátok). — Szakdolgozat, Kőzettan-Geokémiai Tanszék MSc, 97 p.

Moriya, I., Okuno, M., Nakamura, E., Szakács, A. \& Seghedi, I. 1995: Last eruption and its 14C age of Ciomadul volcano, Romania. - Summaries of Researches using AMS at Nagoya University 6, 82-91.

MoriYa, I., OKuno, M., NAKAMURA, T., ONO, K. A. S. \& SEGHEDI, I. 1996: Radiocarbon ages of charcoal fragments from the pumice flow deposits of the last eruption of Ciomadul volcano, Romania. - Summaries of Researches using AMS at Nagoya University 7/3, $252-255$.

Pécskay, Z., Lexa, J., A., S., Balogh, K., Seghedi, I., Konecny, V., Kovács, M., Márton, E., Kaliciak, M., Széky-Fux, V., Póka, T., Gyarmati, P., Edelstein, O., Rosu, E. \& ZeC, B. 1995: Space and time distribution of Neogene-Quaternary volcanism in the CarpathoPannonian Region. — In: Downes, H. \& VASELLI, O. (eds): Neogene and Related Magmatism in the Carpatho-Pannonian Region. — Acta Vulcanologica 7, 15-28.

Pécskay, Z., LeXa, J., Szakács, A., Seghedi, I., Balogh, K., KonecnÝ, V., Zelenka, T., Kovacs, M., Póka, T., FülöP, A., Márton, E., Panaiotu, C. \& Cvetkovic, V. 2006: Geochronology of Neogene magmatism in the Carpathian arc and intra-Carpathian area. Geologica Carpathica 57/6, 511-530.

Phillips, D. \& Matchan, E. L. 2013: Ultra-high precision ${ }^{40} \mathrm{Ar} /{ }^{39} \mathrm{Ar}$ ages for Fish Canyon Tuff and Alder Creek Rhyolite sanidine: New dating standards required? — Geochimica et Cosmochimica Acta 121, 229-239. http://doi.org/10.1016/j.gca.2013.07.003

Popa, M., Radulian, M., Grecu, B., Popescu, E. \& Placinta, A. O. 2005: Attenuation in Southeastern Carpathians area: Result of upper mantle inhomogeneity. - Tectonophysics 16, 155-161. http://doi.org/10.1016/j.tecto.2004.12.037

Press, W. H., Teukolsky, S. A., Vetterling, W. T. \& Flannery, B. P. 2002: Numerical Recipes: The Art of Scientific Computing. Cambridge University Press, Cambridge, 949 p. 
REID, M. R. 2008: How Long Does It Take to Supersize an Eruption? — Elements 4/1, 23. http://doi.org/10.2113/GSELEMENTS.4.1.23

Reid, M. R., CoAth, C. D., Mark Harrison, T. \& Mckeegan, K. D. 1997: Prolonged residence times for the youngest rhyolites associated with Long Valley Caldera: ${ }^{230} \mathrm{Th}-{ }^{238} \mathrm{U}$ ion microprobe dating of young zircons. — Earth and Planetary Science Letters 150/1-2, 2739. http://doi.org/10.1016/S0012-821X(97)00077-0

REINERS, P. W. 2005: Zircon (U-Th)/He Thermochronometry. — Reviews in Mineralogy and Geochemistry 58/1, 151-179. http://doi.org/ 10.2138/rmg.2005.58.6

ReIners, P. W. \& Brandon, M. T. 2006: Using Thermochronology To Understand Orogenic Erosion. — Annual Review of Earth and Planetary Sciences 34/1, 419-466. http://doi.org/10.1146/annurev.earth.34.031405.125202

REINERS, P. W. \& FARLEY, K. A. 1999: Helium diffusion and (U-Th)/He thermochronometry of titanite. _ Geochimica et Cosmochimica Acta 63/22, 3845-3859. http://doi.org/10.1016/S0016-7037(99)00170-2

Reiners, P. W., Spell, T. L., Nicolescu, S. \& ZANETTI, K. A. 2004: Zircon (U-Th)/He thermochronometry: He diffusion and comparisons with ${ }^{40} \mathrm{Ar} /{ }^{39} \mathrm{Ar}$ dating. — Geochimica et Cosmochimica Acta 68/8, 1857-1887. http://doi.org/10.1016/j.gca.2003.10.021

Robert, J., Miranda, C. F. \& MuXart, R. 1969: Determination of the Half-Life of ${ }^{231}$ Pa by Microcalorimetry. — Radiochim. Acta 11, $104-108$.

Royden, L., Horváth, F. \& Rumpler, J. 1983: Evolution of the Pannonian Basin System: 1. Tectonics. — Tectonics 2/1, 63-90. http://doi.org/10.1029/TC002i001p00063

Schildgen, T. F., Hodges, K. V., Whipple, K. X., Reiners, P. W. \& Pringle, M. S. 2007: Uplift of the western margin of the Andean plateau revealed from canyon incision history, southern Peru. — Geology 35/6, 523-526. http://doi.org/10.1130/G23532A.1

Schмiт, A. K. 2011: Uranium Series Accessory Crystal Dating of Magmatic Processes. - Annual Review of Earth and Planetary Sciences 39/1, 321-349. http://doi.org/10.1146/annurev-earth-040610-133330

Schmitt, A. K., Stockli, D. F. \& HAusback, B. P. 2006: Eruption and magma crystallization ages of Las Tres Vírgenes (Baja California) constrained by combined ${ }^{230} \mathrm{Th} /{ }^{238} \mathrm{U}$ and (U-Th)/He dating of zircon. — Journal of Volcanology and Geothermal Research 158/3-4, 281-295. http://doi.org/10.1016/j.jvolgeores.2006.07.005

Schmitt, A. K., Stockli, D. F., Niedermann, S., Lovera, O. M. \& Hausback, B. P. 2010: Eruption ages of Las Tres Vírgenes volcano (Baja California): A tale of two helium isotopes. — Quaternary Geochronology 5/5, 503-511. http://doi.org/10.1016/j.jvolgeores. 2006.07.005

Schmitt, A. K., Martín, A., Stockli, D. F., FArley, K. A. \& Lovera, O. M. 2013: (U-Th)/He zircon and archaeological ages for a late prehistoric eruption in the Salton Trough (California, USA). — Geology 41/1, 7-10. http://doi.org/10.1130/G33634.1

Schmitt, A. K., Danišík, M., Siebel, W., Elitok, Ö., Chang, Y.-W. \& Shen, C.-C. 2014: Late Pleistocene zircon ages for intracaldera domes at Gölcük (Isparta, Turkey). - Journal of Volcanology and Geothermal Research 286, 24-29. http://doi.org/10.1016/ j.jvolgeores.2014.08.027

SchoENE, B. \& Bowring, S. A. 2007: Determining accurate temperature-time paths from U-Pb thermochronology: An example from the Kaapvaal craton, southern Africa. — Geochimica et Cosmochimica Acta 71/1, 165-185. http://doi.org/10.1016/j.gca.2006.08.029

Seghedi, I., SzakÁcs, A., Udrescu, C., Stoian, M. \& Grabari, G. 1987: Trace element geochemistry of the South Hargitha volcanics (East Carpathians): calc-alkaline and shoshonitic association. _ Dari de Seama ale Sedintelor Institutul de Geologie si Geofizica 72-73, 381-397.

SEGHEDI, I. \& Downes, H. 2011: Geochemistry and tectonic development of Cenozoic magmatism in the Carpathian-Pannonian region. — Gondwana Research 20, 655-672. http://doi.org/10.1016/j.gr.2011.06.009

Seghedi, I., Downes, H., HARAngi, S., MAson, P. R. D. \& PÉCSkAY, Z. 2005: Geochemical response of magmas to Neogene-Quaternary continental collision in the Carpathian-Pannonian region: A review. — Tectonophysics 410/1-4, 485-499. https://doi.org/10.1016/ j.tecto.2004.09.015

Seghedi, I., Downes, H., Szakács, A., Mason, P. R. D., Thirlwall, M. F., Rosu, E., Pécskay, Z., Marton, E. \& Panaiotu, C. 2004: Neogene-Quaternary magmatism and geodynamics in the Carpathian-Pannonian region: A synthesis. — Lithos 72, 117-146. http://doi.org/10.1016/j.lithos.2003.08.006

Seghedi, I., Mațenco, L., Downes, H., Mason, P. R. D., Szakács, A. \& Pécskay, Z. 2011: Tectonic significance of changes in postsubduction Pliocene-Quaternary magmatism in the south east part of the Carpathian-Pannonian Region. — Tectonophysics 502/12, 146-157. http://doi.org/10.1016/j.tecto.2009.12.003

SPERnER, B., IOANE, D. \& LilLIE, R. J. 2004: Slab behaviour and its surface expression: New insights from gravity modelling in the SE Carpathians. — Tectonophysics 382, 51-84. http://doi.org/10.1016/j.tecto.2003.12.008

Spotila, J., Farley, K. A. \& Sieh, K. 1998: Uplift and erosion of the San Bernardino Mountains associated with transpression along the San Andreas fault, California, as constrained by radiogenic helium thermochronometry. — Tectonics 17/3, 360-378. http://doi.org/ 10.1029/98TC00378

StRUTt, R. J. 1905: On the Radio-Active Minerals. — Proceedings of the Royal Society of London. Series A 76/508, 88-101.

SzABó, C., HARANGi, S. \& Csontos, L. 1992: Review of neogene and quaternary volcanism of the Carpathian-Pannonian region: a review. — Tectonophysics 208, 243-256. http://doi.org/10.1016/0040-1951(92)90347-9

SZAKÁCS, A. \& SEGHEDI, I. 1986: Chemical diagnosis of the volcanics from the southeasternmost part of the Harghita Mountains proposal for a new nomenclature. - Revue Roumaine de Géologie 30, 41-48.

SzaKÁcs, A., SEghedi, I. \& PÉCSKay, Z. 1993: Pecularities of South Hargitha Mts. as the terminal segment of the Carpathian Neogene to Quaternary volcanic chain. - Revue Roumaine de Géologie Géophysique et Géographie, Géologie 37, 21-37.

SZAKÁCS, A., SEGHEDI, I. \& PÉCSKAY, Z. 2002: The most recent volcanism in the Carpathian-Pannonian Region. Is there any volcanic hazard? — Geologica Carpathica Special Issue, Proceedings of the XVIIth Congress of Carpathian-Balkan Geological Association 53, $193-194$.

SzakÁcs, A., SEghedi, I., PÉcskay, Z. \& Mirea, V. 2015: Eruptive history of a low-frequency and low-output rate Pleistocene volcano, Ciomadul, South Harghita Mts., Romania. — Bulletin of Volcanology 77/2, 1-19. http://doi.org/10.1007/s00445-014-0894-7 
TAgami, T., Farley, K. A. \& Stockli, D. F. 2003: (U-Th)/He geochronology of single zircon grains of known Tertiary eruption age. Earth and Planetary Science Letters 207/1-4, 57-67. http://doi.org/10.1016/S0012-821X(02)01144-5

Tripathy-Lang, A., Hodges, K. V., Monteleone, B. D. \& VAn Soest, M. C. 2013: Laser (U-Th)/He thermochronology of detrital zircons as a tool for studying surface processes in modern catchments. — Journal of Geophysical Research: Earth Surface 118/3, 1333-1341. http://doi.org/10.1002/jgrf.20091

Vinkler, A. P., Harangi, S., Ntaflos, T. \& Szakács, A. 2007: A Csomád vulkán (Keleti-Kárpátok) horzsaköveinek kőzettani és geokémiai vizsgálata — petrogenetikai következtetések. — Földtani Közlöny 137/1, 103-128.

WAGNER, G. A. 1979: Correction and Interpretation of Fission Track Ages. — In: JÄGER, E. \& HunzIKER, J. C. (eds): Lectures in Isotope Geology. Berlin, Heidelberg, 170-177. http://doi.org/10.1007/978-3-642-67161-6_11

WERNICKE, R. S. \& LiPPOLT, H. J. 1997: (U+Th)-He evidence of Jurassic continuous hydrothermal activity in the Schwarzwald basement, Germany. — Chemical Geology 138/3-4, 273-285. http://doi.org/10.1016/S0009-2541(97)00020-X

Wolf, R. A., FArLey, K. A. \& Silver, L. T. 1996: Helium diffusion and low-temperature thermochronometry of apatite. — Geochimica et Cosmochimica Acta 60/21, 4231-4240. http://doi.org/10.1016/S0016-7037(96)00192-5

Wolff, R., Dunkl, I., Kempe, U. \& Von Eynatten, H. 2015: The Age of the Latest Thermal Overprint of Tin and Polymetallic Deposits in the Erzgebirge, Germany: Constraints from Fluorite (U-Th-Sm)/He Thermochronology. — Economic Geology 110/8, 2025-2040. http://doi.org/10.2113/econgeo.110.8.2025

Zeitler, P. K., Herczeg, A. L., Mcdougall, I. \& Honda, M. 1987: U-Th-He dating of apatite: A potential thermochronometer. Geochimica et Cosmochimica Acta 51/10, 2865-2868. http://doi.org/10.1016/0016-7037(87)90164-5

ZIEGLER, J. F. 1977: Helium: stopping powers and range in all element matter. — New York: Pergamon Press, 367 p.

Kézirat beérkezett: 2016 12. 01. 